TARNOWSKIE STUDIA TEOLOGICZNE 34 (2015) NR 2, S. 5-46

http://dx.doi.org/10.15633/tst.1638

ks. Jarosław R. Marczewski ${ }^{1}$

KATOLICKI UNIWERSYTET LUBELSKI JANA PAWŁA II

\title{
Pięć lat internowania. Biskup lubelski Marian Leon Fulman na plebanii kościoła kolegiackiego pw. św. Małgorzaty w Nowym Sączu (1940-1945)
}

Siedemdziesiąta rocznica śmierci biskupa lubelskiego Mariana Leona Fulmana, stanowi tego rodzaju cezurę czasową, która większości współcześnie żyjących uniemożliwia osobiste sięgnięcie pamięcią w tak odległą przeszłość. Wyłącznie ludzie należący do najstarszego pokolenia mogą przypomnieć sobie tę postać i wydobyć ze skarbnicy własnego życiowego doświadczenia okruchy zdarzeń związanych z osobą lubelskiego pasterza. Tym ważniejsza staje się w tych okolicznościach rola historyka Kościoła, który idąc tropem naukowego powołania i duchowego pożytku Czytelnika, jest w stanie źródłowo opracować i właściwie zinterpretować dziejowe fakty. Składają się na nie także te zdarzenia, wcale nie epizodyczne, które związane były z ostatnim, dramatycznym etapem życia bp. Fulmana - jego kilkuletnim, przymusowym pobytem na plebanii kościoła kolegiackiego pw. św. Małgorzaty w Nowym Sączu w dobie niemieckiej okupacji Polski podczas drugiej wojny światowej.

\section{W dobie zaborów i odzyskanej wolności}

Marian Leon Fulman pochodził ze Starego Miasta, oddalonego kilka kilometrów od Konina, a więc z zachodnich krańców ówczesnego Królestwa Kongresowego, pozostającego pod zaborem rosyjskim ${ }^{2}$. Urodził się 27 marca

Ks. Jarosław R. Marczewski, kapłan archidiecezji lubelskiej, doktor habilitowany teologii w zakresie historii Kościoła, adiunkt w Katedrze Historii Kościoła w Czasach Nowożytnych i Dziejów Teologii w Instytucie Historii Kościoła i Patrologii KuL, dyrektor Archiwum Archidiecezjalnego Lubelskiego, rektor Metropolitalnego Seminarium Duchownego w Lublinie.

2 Leksykograficzne informacje dotyczące tej postaci znalazły się w następujących artykułach: Z. Goliński, Fulman Marian Leon, [w:] Polski słownik biograficzny, t. 7, red. W. Konop- 
1866 roku, w niezwykle trudnym dla Kościoła i narodu polskiego okresie po powstaniu styczniowym. Stosunkowo dostatni dom rodziców, drobnych przemysłowców, dał mu możliwość podjęcia nauki i pozwolił na wyrobienie intelektualnej, dydaktycznej i organizacyjnej pasji. Jeszcze jako alumn seminarium rodzinnej diecezji kujawsko-kaliskiej został skierowany na dalsze studia do Rzymskokatolickiej Akademii Duchownej w Petersburgu, która spełniała w praktyce rolę wyższej uczelni przygotowującej przyszłe kadry kierownicze dla Kościoła na całym terytorium znajdującym się pod władzą carską. W zamyśle władz zaborczych petersburskie studia, podlegające daleko idącej kontroli państwowej, miały stanowić dobry sposób na wdrożenie przyszłych duchownych w tryby carskiej machiny urzędniczej i na ich pełne zlojalizowanie. Cel ten udawało się osiągnąć jednak tylko w pewnej liczbie przypadków osób o słabszych charakterach. Marian Fulman nie należał do tej grupy. Co więcej, w przekonaniu o potrzebie podnoszenia własnych kwalifikacji intelektualnych i poziomu moralno-duchowego, przystąpił wraz z innymi kolegami do tajnego stowarzyszenia samokształceniowego. Nie miało ono wprost charakteru patriotycznego czy w jakiejkolwiek mierze antypaństwowego, ale z pewnością wyrastało z pogłębionego poczucia własnej tożsamości katolickiej i narodowej3

Po święceniach kapłańskich przyjętych 13 maja 1889 roku i uzyskaniu stopnia magistra ks. Fulman został zaangażowany jako wykładowca teologii dogmatycznej i liturgiki w seminarium duchownym we Włocławku, był także ceremoniarzem katedralnym oraz prefektem w szkole realnej. $\mathrm{Na}$ tym stanowisku, poza talentami i pracowitością, szybko ujawniła się jego postawa patriotyczna oraz pełne oddanie Kościołowi w zakresie troski o przynależne mu prawa, kwestionowane w praktyce w okolicznościach carskiej opresji. Praktyką państwowo-kościelną było w tym czasie celebrowanie tzw. nabożeństw galowych związanych z modlitwą o pomyślność państwa i rodziny panującej. Narzucony Kościołowi katolickiemu pod zaborem rosyjskim obowiązek ich celebrowania był szczególnie nieprzyjemnym przejawem imperialnych rządów. W duchu kościelnego legalizmu ówczesnej

czyński, Kraków 1948-1958, s. 181-183; K. Rulka, Fulman Marian Leon, [w:] Słownik polskich teologów katolickich, t. 7, red. L. Grzebień, Warszawa 1983, s. 412-416; E. Walewander, Fulman Marian Leon, [w:] Encyklopedia katolicka, t. 7, red. L. Bieńkowski i in., Lublin 1989, kol. 757-758.

3 Por. R. Prejs, Biskup Marian Leon Fulman jako teolog i pisarz religijny, [w:] Pater Ecclesiae Lublinensis. Studia $w$ 65. rocznicę śmierci biskupa Mariana Leona Fulmana (1866-1945), red. J. R. Marczewski, Lublin 2010, s. 186-187. 
doby sprawowano je, co prawda, sumiennie, ale w poczuciu narodowej krzywdy. Poza schematem różnego rodzaju rocznic dochodziły tu jeszcze wydarzenia szczególne i okazjonalne. Tak było m.in. 17 października 1891 roku, gdy car Aleksander III wraz z rodziną uniknął przykrych następstw katastrofy kolejowej, w której uczestniczył. Inaczej jednak niż w przypadku katolickich świątyń parafialnych, placówka, w której ks. Fulman pełnił funkcję prefekta, została $\mathrm{z}$ nakazu miejscowych władz zobligowana do wzięcia udziału w nabożeństwie prawosławnym w szkolnej kaplicy. Stanowczy sprzeciw ks. Fulmana wobec łamania porządku wyznaniowego poskutkował zwolnieniem ze stanowiska we włocławskiej szkole realnej, poczynając od stycznia 1892 roku.

Tymczasem w rezultacie odkrycia w marcu 1893 roku wspomnianego związku kapłańskiego absolwentów Akademii Duchownej, który władze carskie potraktowały niewspółmiernie do właściwego stanu rzeczy jako poważne wykroczenie i zagrożenie dla ładu państwowego, ks. Fulman trafił pod ścisłą obserwację policji. W maju 1894 roku przeprowadzono u niego rewizję i mimo obiektywnie błahych dowodów winy został aresztowany i w początkach stycznia 1895 roku osadzony na warszawskim Pawiaku. W wyniku wytoczonego procesu został skazany na przymusowy, pięcioletni wyjazd w głąb Rosji. Szczęśliwie, dzięki ogłoszonej amnestii z okazji koronacji cara Mikołaja II jedynie przez półtora roku przebywał jako zesłaniec w Niżnym Nowogrodzie. Ciesząc się względną swobodą, zdołał tam nawiązać kontakt z miejscowymi Polakami, odprawiał msze święte, głosił kazania, a nawet potajemnie nauczał polską młodzież religii i ojczystego języka.

Po powrocie w 1896 roku w rodzinne strony ks. Fulman nie miał już możliwości kontynuowania pracy dydaktycznej. Nabył natomiast szerokiego doświadczenia duszpasterskiego i administracyjnego, jako proboszcz kolejnych, coraz większych i bardziej wymagających placówek, takich jak Lubień, Kowal, Rozprza, na probostwie w liczącej wówczas sześćdziesiąt tysięcy wiernych parafii częstochowskiej kończąc. Nie utracił wszakże kontaktu z nauką i z pożytkiem rozwijał swoje zainteresowania teologiczne. Stał się powszechnie znanym pisarzem religijnym, redaktorem i wydawcą, przyczyniając się do powstania czasopisma „Wiadomości Pasterskie”.

4 Por. Z. Starnawski, Martyrologium duchowieństwa diecezji lubelskiej w latach 1939-1945. Słownik biograficzny, s. 5-9 [mps w Archiwum Archidiecezjalnym Lubelskim]. 
Nominacja tej ogólnie znanej postaci na biskupa lubelskiego zbiegła się z odzyskaniem przez Polskę niepodległości. Stolica Apostolska wyznaczyła ks. Fulmana na pasterza diecezji lubelskiej 24 września 1918 roku. Święcenia biskupie otrzymał z rąk abp. Aleksandra Kakowskiego 17 listopada w archikatedrze warszawskiej. Natomiast 1 grudnia 1918 roku odbył się ingres biskupa do katedry lubelskiej. Warto odnotować, że przybywającemu do Lublina pasterzowi towarzyszyła od rogatek miasta kompania polskiego wojska. Na widok żołnierzy w narodowych mundurach i barwach biskup zareagował głębokim wzruszeniem, któremu dał serdeczny wyraz w słowach skierowanych wówczas do towarzyszącego mu duchowieństwa. Wkrótce biskup w praktyce ujawnił poparcie dla sprawy narodowej, kiedy w okolicznościach natarcia bolszewickiego w 1920 roku pozostał na swojej placówce i zabronił komukolwiek z duchownych opuszczania wiernych. Żaden z tych kapłanów, którzy mimo zarządzenia pasterza porzucili parafie, nie powrócił na zajmowane wcześniej stanowisko 5 .

Po ustabilizowaniu się granic państwowych, w nowych warunkach politycznych, wszechstronnie uzdolniony, doświadczony, wciąż energiczny, ledwie nieco ponad pięćdziesięcioletni bp Fulman objawił w pełni swoje możliwości, dając koncepcyjne, strukturalne i duchowe podstawy do odnowy i rozwoju lokalnego Kościoła, który został powierzony jego pasterskiej trosce. Trzeba bowiem pamiętać, że życie religijne na Lubelszczyźnie i Chełmszczyźnie w okresie zaborów podlegało szczególnemu uciskowi. Miało to związek ze specyfiką tego terenu, gdzie zamieszkiwała ludność zmieszana etnicznie i wyznaniowo i gdzie władze carskie przeprowadziły w ostatnich dekadach xıx wieku akcję likwidacji Kościoła unickiego, brutalnie włączając jego wyznawców w szeregi ludności prawosławnej.

Zaborcy rozumieli wszakże, że sam akt administracyjny nie wystarczy, o ile moc represji nie będzie zniechęcać byłych unitów do szukania duszpasterskiej pomocy w świątyniach obrządku łacińskiego. Dlatego też szereg działań rosyjskich urzędników i policji skierowany był przeciwko swobodzie wykonywania kultu religijnego w parafiach diecezji lubelskiej położonych na tym obszarze. W konsekwencji zlikwidowano niektóre z nich, zakazano tworzenia nowych, zabroniono wznoszenia i remontowania budynków sakralnych, utrudniano duchowieństwu katolickiemu

5 Por. E. Walewander, Biskup Marian Leon Fulman (1866-1945) - życie i dzieło, [w:] Biskup lubelski Marian Leon Fulman. Pedagog trudnych lat, red. E. Walewander, Lublin 2010, s. 126. 
gromadzenie i katechizowanie dzieci, reglamentowano udawanie się z posługą spowiedniczą i wizytą do chorych, zredukowano działalność bractw kościelnych i zakazano tworzenia nowych, zabroniono wprowadzania nowych nabożeństw kościelnych, ograniczono procesje i wszelkie zewnętrzne przejawy kultu.

Pomimo nastania względnej wolności związanej z ukazem tolerancyjnym i rewolucją 1905 roku bp Fulman zastał diecezję o zapóźnionej infrastrukturze, słabszej organizacji, mniejszej żywotności duszpasterskiej, nasyconą duchowieństwem tyleż ideowym, co nieraz złamanym duchowo lub moralnie oddziaływaniem carskiego prawosławia. Dodatkowo wysoki odsetek ludności zamieszkującej teren diecezji stanowili wyznawcy religii mojżeszowej i prawosławni. Silne były także wpływy ideologii lewicowej. W tym kontekście konieczna stała się całościowa przebudowa diecezji. Trzeba przyznać, że bp Fulman podołał temu zadaniu, nadając lokalnemu Kościołowi kształt i wigor na wiele późniejszych dziesięcioleci. Szeregi organizacji religijnych, dotąd dyskryminowanych, których działalność ograniczała się do budynku kościoła, zasiliły stowarzyszenia katolickie, stawiające sobie za cel ogarnięcie duchem Ewangelii całej przestrzeni społecznej ${ }^{6}$. Uzupełniono także przestarzałą sieć administracji kościelnej, tworząc ponad osiemdziesiąt nowych parafiił. Bujny rozwój nastąpił w dziedzinie duszpasterstwa, wprowadzono powszechnie szereg nowych nabożeństw, na które uprzednio niechętnie patrzyły władze zaborcze, jak choćby nabożeństwo majowe czy czerwcowe ${ }^{8}$. Po raz pierwszy od wielu dziesięcioleci na ulice miast wyszły procesje eucharystyczne Bożego Ciała ${ }^{9}$. Powołano do życia wiele instytucji przykościelnych, takich jak placówki charytatywne, szkoły katolickie z nowoczesnym Gimnazjum Biskupim na czele. W placówkach

6 Por. M. Nabożny, Biskup Marian Leon Fulman wobec organizacji kościelnych i stowarzyszeń katolickich $w$ diecezji lubelskiej w świetle „Wiadomości Diecezjalnych Lubelskich” $z$ lat 1918-1945, [w:] Pater Ecclesiae Lublinensis. Studia w 65. rocznicę śmierci biskupa Mariana Leona Fulmana (1866-1945), dz. cyt., s. 249-292.

7 Por. J. Kumor-Mielnik, Geografia historyczna Kościoła lubelskiego, [w:] Atlas historyczny (archi)diecezji lubelskiej 1805-2010, red. H. Gapski, Lublin 2011, s. 82.

8 Por. P. Petryk, Liturgia w rozumieniu biskupa Mariana Leona Fulmana, [w:] Biskup lubelski Marian Leon Fulman. Pedagog trudnych lat, dz. cyt., s. 198-202.

9 Por. tenże, Msza św. i kult eucharystyczny w koncepcji duszpasterstwa biskupa Mariana Leona Fulmana, [w:] Pater Ecclesiae Lublinensis. Studia w 65. rocznicę śmierci biskupa Mariana Leona Fulmana (1866-1945), dz. cyt., s. 231-233. 
oświatowych pojawiły się lekcje religii. Nie bez znaczenia dla sytuacji diecezji lubelskiej był również fakt powstania w 1918 roku Katolickiego Uniwersytetu Lubelskiego $^{10}$. W 1928 roku odprawiono pierwszy w dziejach diecezji synod kościelny, który uporządkował prawo i praktykę duszpasterską po okresie zaborów oraz wyznaczył kierunki pracy na przyszłośćn ${ }^{11}$. Nie byłoby to możliwe bez dalekosiężnej wizji i czynnego zaangażowania ówczesnego rządcy diecezji.

Warto zauważyć, że sukcesy osiągnięte przez bp. Fulmana na polu eklezjalnym wynikały nie tylko $\mathrm{z}$ jego miłości do Kościoła, ale także z głębokich pobudek patriotycznych. W liście pasterskim wydanym w związku z objęciem diecezji biskup zawarł swój program pracy, który przedstawił w następujący sposób: „Najpilniejszym zadaniem moim będzie takie zorganizowanie pracy kapłańskiej i życia religijnego wśród wiernych, i to w każdej dziedzinie, aby wszystko było odnowione w Chrystusie. Dobro duchowe i materialne naszej Ojczyzny tylko wówczas będzie istotnie trwałe, gdy będzie zbudowane według idei Chrystusowej. Co przez tyle czasu było rozbijane i rozkruszane nieledwo na pył, to teraz musi być powiązane i zjednoczone, i żyć. W tym celu ugruntowanie wiary katolickiej w narodzie, obrona interesów narodowych, zwłaszcza w tej części Ojczyzny naszej, dalej rozwój cnót religijnych i obywatelskich, jedność i tężyzna narodu będą mi szczególnie leżały na sercu" ${ }^{\prime 2}$.

Dosadnie brzmiały również wezwania zawarte w liście, a skierowane do lubelskich kapłanów, co zapewne łączyło się z osobistym życiowym doświadczeniem biskupa: „Kapłan obowiązany jaśnieć wielką miłością Ojczyzny. Obok obowiązków apostolskich spoczywają na nim i obowiązki obywatelskie. Życie społeczne, naukowe i towarzyskie, a nawet i polityczne winno go obchodzić. Jak w pełnieniu obowiązków patriotycznych nikomu nie powinien pozwolić się wyprzedzić, tak i z przysługujących mu praw obywatelskich nie może dać się wrogom Kościoła wyzuć. Jakkolwiek najwdzięczniej

${ }^{10}$ Por. E. Walewander, Biskup Marian Leon Fulman, art. cyt., s. 126; S. Wilk, Biskup Marian Leon Fulman jako Wielki Kanclerz KUL, [w:] Biskup lubelski Marian Leon Fulman. Pedagog trudnych lat, dz. cyt., s. 131-145.

${ }^{11}$ Por. S. Dubiel, Zasługi biskupa Mariana Leona Fulmana w stworzeniu prawa diecezjalnego, [w:] Biskup lubelski Marian Leon Fulman. Pedagog trudnych lat, dz. cyt., s. 147-172.

${ }^{12}$ List pasterski bpa M. L. Fulmana $z 1$ grudnia 1918 r., „Wiadomości Diecezjalne Lubelskie” [dalej: WDL] 1 (1918) nr 1, s. 7-8. 
i najprzystojniej mu jest pracować w dziedzinie opieki i miłosierdzia, jednak i w innej dziedzinie pracy publicznej ma brać czynny udział"13.

Dodatkowo biskup oświadczał jeszcze: „Wstępując na stolicę biskupią lubelską, do ciebie, narodzie polski, zwracam się ze słowem serdecznym, jako krew z krwi twojej i jako duch z ducha twego i ślubuję ci, iż twoje szczęście doczesne i wieczne - twoje zbawienie i uświęcenie - twoja wolność i potęga - twoja świetność i pomyślność dniem i nocą będzie przedmiotem najtkliwszej miłości i troski mojej, zarazem i treścią mej najgorętszej modlitwy do Boga"14.

Wobec takich deklaracji, i - co ważniejsze - wobec potwierdzającej je wieloletniej działalności, nie dziwi fakt, że katastrofa państwa i klęska narodowa drugiej wojny światowej stała się także osobistą tragedią lubelskiego biskupa, która przełożyła się na dramatyczne wydarzenia ostatnich lat jego życia.

\section{W trybach niemieckiej sprawiedliwości}

Na wiadomość o niemieckiej agresji na Polskę bp Fulman zareagował natychmiast. Jak przystało na polskiego biskupa, zatroskanego o najbliższą przyszłość Ojczyzny i wiernych powierzonych jego trosce, zarządził i odprawił 1 września 1939 roku w godzinach popołudniowych mszę świętą polową przed lubelską katedrą. Następnego dnia rano zaczęły się naloty Luftwaffe na miasto. Zbombardowano wówczas lubelską Wytwórnię Samolotów E. Plagego i T. Leśkiewicza, a także pobliskie dzielnice Bronowice, Kośminek i Dziesiątą. Zginęło około 200 mieszkańców. Pochówek, choć dokonany nocą z obawy przed kolejnymi nalotami, zyskał specjalną rangę, jako że egzekwiom przewodniczył biskup pomocniczy Władysław Goral $^{15}$. Z pewnością wynikało to $\mathrm{z}$ ustaleń $\mathrm{z}$ bp. Fulmanem, który zarówno z powodu wieku, jak i przebytej wiosną i latem choroby serca nie był w najlepszej kondycji. Podobnie było zapewne z udziałem bp. Gorala w przygotowaniu wraz z cywilnymi oficjelami odezwy i apelów do ludności, które zamieszczono w prasie i wydano w postaci ulotek. Niewątpliwie również zaangażowanie ks. Zygmunta Surdackiego w prace powołanego

13 Tamże, s. 11.

${ }_{14}$ Tamże, s. 7 .

15 Por. Archiwum Archidiecezjalne Lubelskie [dalej: AAL], Rep 60 IIb G57, Akta osobowe bp. Władysława Gorala, Notatnik z kazaniami, s. 116-117, 119-120. 
3 września Miejskiego Obywatelskiego Komitetu Społecznego miało pełne poparcie ordynariusza $^{16}$.

W kolejnych dniach wojny Niemcy kontynuowali naloty bombowe na Lublin. W dniach 4 i 5 września ucierpiała dzielnica Wrotków, a następnie koszary wojskowe i most kolejowy. Śródmieście i Stare Miasto zostały zbombardowane 9 września. Na skutek użycia bomb burzących i zapalających zniszczono około 200 budynków mieszkalnych i kilka gmachów użyteczności publicznej. Tego dnia ciężko ucierpiały pałac biskupi, seminarium duchowne, plac i budynki przykatedralne, a także sama katedra, która straciła część dachu nad nawą główną, jedną wieżę, frontowy portyk z kolumnami i zakrystię. Zarysowane zostały ściany katedry, potrzaskane niektóre elementy wystroju wnętrza, w tym także wielki żyrandol. Po zajęciu Lublina 17 września przez wojska niemieckie dokonany został rabunek cenniejszych elementów mienia katedralnego, w tym xIV-wiecznej chrzcielnicy, kielichów mszalnych, biskupich szat liturgicznych, natomiast liczne inne sprzęty i paramenty liturgiczne zdewastowano. Wedle niektórych opinii mogło to stanowić działania odwetowe za odważną i zaangażowaną postawę biskupa i duchowieństwa w pierwszych dniach wojny ${ }^{17}$.

Tego samego dnia grupa żołnierzy niemieckich z wydzielonego oddziału 4 Dywizji Iv Korpusu, który zdobył Lublin, na czele $\mathrm{z}$ oficerem w randze pułkownika, wkroczyła do pałacu biskupiego i zachowując się arogancko, domagała się wydania im obiadu. Żądanie zostało spełnione, ale bp Fulman nie spotkał się osobiście z przybyłymi Niemcami, zlecił jedynie obowiązki gospodarza jednemu ze swoich współpracowników. Przez kolejny miesiąc biskup skutecznie unikał oficjalnego kontaktu z okupantami, zarówno osobistego, jak też przez jakiegokolwiek delegata ${ }^{18}$.

Wkrótce, poczynając od 9 listopada, Niemcy zaczęli realizować w Lublinie szerszy plan, mający na celu likwidację grup przywódczych i inteligencji polskiej. Wynikał on z decyzji, jakie zapadły na najwyższych szczeblach hitlerowskiego aparatu państwowego ${ }^{19}$. Dodatkowym motywem precyzującym

${ }^{16}$ Por. M. Wieliczko, Kontekst historyczny losów biskupa Mariana Leona Fulmana w czasie drugiej wojny światowej, [w:] Biskup lubelski Marian Leon Fulman. Pedagog trudnych lat, dz. cyt., s. 93.

17 Por. tamże, s. 94-95.

18 Por. Z. Goliński, Diecezja w latach 1939-1944. Lublin-Oranienburg-Nowy Sącz-Lublin. Lata 1939-1945 w życiu J.E. Ks. Bpa Fulmana, wDL 23 (1946) nr 1, s. 22.

19 Por. M. Wieliczko, Kontekst historyczny, art. cyt., s. 100-101. 
datę podjętych $\mathrm{d}_{z}$ iałań była przypadająca rocznica odzyskania niepodległości i związane $\mathrm{z}$ nią polskie święto państwowe. W zastosowanym paradygmacie eksterminacji mieściło się par excellence duchowieństwo katolickie, a zwłaszcza jego kierownicze kręgi na czele $\mathrm{z}$ biskupami. Zaaresztowano więc księży z seminarium duchownego, Katolickiego Uniwersytetu Lubelskiego, ze szkół lubelskich, parafii pw. Nawrócenia św. Pawła Apostoła i pw. św. Michała Archanioła, jak również duchownych przypadkowo spotkanych na ulicach Lublina. W kolejnych dniach dołączyli do tego grona niektórzy duchowni z wybranych miejscowości diecezji lubelskiej ${ }^{20}$.

Biskup Fulman został aresztowany wraz z bp. Goralem, pracownikami kurii i sądu biskupiego oraz pozostającymi jeszcze na wolności po pierwszych zatrzymaniach profesorami seminarium duchownego. Stało się to w godzinach wczesnopopołudniowych 17 listopada, a więc dokładnie w 21. rocznicę konsekracji biskupiej pasterza. Kilka dni później do tej grupy dołączyli jeszcze dwaj wikariusze katedralni. Niemiecka tajna policja Gestapo najpierw wkroczyła do seminarium, aresztując tamtejszych kapłanów, których następnie zaprowadzono do kurii, gdzie zatrzymano przebywających tam księży, zarówno urzędników, jak też interesantów, a także miejscową służbę i siostry zakonne. W pałacu biskupim aresztowania obu hierarchów dokonali członkowie niemieckiej policji politycznej sD. Biskupa Fulmana, próbującego dowiedzieć się o przyczynę zatrzymania, poinformowano, że miało ono jakoby związek z przechowywaniem broni w pałacu biskupim. Po oględzinach i zabezpieczeniu pomieszczeń, około godz. 17 aresztantów - księży biskupów osobnym autem - przewieziono do więzienia na zamku, gdzie znajdowali się już inni duchowni, zatrzymani we wcześniejszych dniach. Biskup Fulman został poddany standardowej procedurze rejestracyjnej, połączonej ze szczegółową, upokarzającą rewizją osobistą. Zgodnie z procedurą odebrano mu pieniądze, zegarek i inne znalezione przy nim drobne przedmioty. Pozostawiono brewiarz, ale dla bezpieczeństwa odarto go ze skórzanej okładki. Obaj biskupi mogli zachować bieliznę i prześcieradło na więzienne łóżko. Zezwolono także, aby dostarczano im obiady z miasta. Przez dwa dni obaj biskupi wraz z kanclerzem kurii przebywali we wspólnej celi, po czym ich rozdzielono, tak że bp Fulman przebywał odtąd w celi

${ }^{20}$ Por. Z. Goliński, Diecezja w latach 1939-1945. Prześladowania niemieckie duchowieństwa $w$ diecezji lubelskiej, wDL 23 (1946) nr 9, s. 330-332. 
pojedynczej $^{21} .19$ listopada kapelan więzienia celebrował w kaplicy mszę świetą niedzielną, w której wziął udział bp Fulman, pozostali duchowni i świeccy aresztanci. Na skutek interwencji Gestapo nabożeństwa w kaplicy zostały następnie na dłuższy czas zakazane, tak iż bp Fulman, trzymany w odosobnieniu, nie widział się ze swymi księżmi, aż do swojego procesu ${ }^{22}$.

Niezwłocznie po aresztowaniu próbę uwolnienia bp. Fulmana podjęła jego bratanica, Eugenia Fulman-Steligowa. Będąc z zawodu lekarzem i znając doskonale stan zdrowia stryja, usiłowała na ścieżce formalnej wystarać się o jego zwolnienie $\mathrm{z}$ więzienia $\mathrm{z}$ powodu choroby serca. Uzyskała w tym celu dodatkowe zaświadczenia, wystawione przez dwóch innych lubelskich lekarzy, którzy zajmowali się bp. Fulmanem jako pacjentem. Interwencja ta zakończyła się całkowitym niepowodzeniem. Co więcej, również cała trójka lekarzy trafiła $\mathrm{z}$ tego powodu na pewien czas do zamkowego aresztu ${ }^{23}$.

Zaplanowane przez Niemców działania skierowane przeciwko lubelskim biskupom i duchowieństwu bezpośrednio zaangażowanemu w wyższych strukturach administracji diecezjalnej zakładały postawienie ich przed policyjnym sądem doraźnym ${ }^{24}$. Sąd taki zebrał się na zamku, w tzw. sali szkolnej, przylegającej do kaplicy, 27 listopada 1939 roku o godz. 15. W jego skład wchodziło dziewięciu umundurowanych oficerów niemieckiego wojska i policji, spośród których najstarszy rangą oficer pełnił funkcję przewodniczącego, sześciu było sędziami orzekającymi, jeden prokuratorem i jeden sekretarzem. Obu biskupów i kanclerza kurii umieszczono w kaplicy, pełniącej doraźnie rolę poczekalni. Pozostałych duchownych i świeckich, którzy byli bądź podsądnymi, bądź świadkami, trzymano na schodach, pod dozorem niemieckich policjantów, każąc stać twarzą do ściany. Biskup Fulman był pytany przez sąd o znalezioną w kurii instrukcję prymasa Augusta Hlonda przesłaną członkom episkopatu na wypadek wojny. Pasterz wyjaśnił, że za-

${ }^{21}$ Por. tenże, Diecezja $w$ latach 1939-1944. Lublin-Oranienburg-Nowy Sacz-Lublin. Lata 1939-1945 w życiu J.E. Ks. Bpa Fulmana, wdL 22 (1945) nr 3, s. 69-71; M. Wieliczko, Kontekst historyczny, art. cyt., s. 103-104.

${ }^{22}$ Por. Z. Goliński, Diecezja w latach 1939-1944. Lublin-Oranienburg-Nowy Sącz-Lublin. Lata 1939-1945 w życiu J.E. Ks. Bpa Fulmana, wdL 22 (1945) nr 3, s. 71; tenże, Diecezja w latach 1939-1945. Prześladowania niemieckie duchowieństwa $w$ diecezji lubelskiej, wDL 23 (1946) nr 10, s. 377.

${ }^{23}$ Por. tenże, Diecezja $w$ latach 1939-1944. Lublin-Oranienburg-Nowy Sacz-Lublin. Lata 1939-1945 w życiu J.E. Ks. Bpa Fulmana, wDL 22 (1945) nr 3, s. 71-72.

${ }^{24}$ Por. M. Wieliczko, Kontekst historyczny, art. cyt., s. 96-103. 
wierała ona wyłącznie dyrektywy duszpasterskie. Indagowano biskupa także o alokucję papieża Piusa XII wygłoszoną na początku wojny, ale biskup nie miał o niej żadnych informacji. Następnie biskup został zapytany o jego wiedzę na temat zabójstwa wójta z Siedliszcza, volksdeutscha, którego uśmiercono w dniu 11 listopada. Również odnośnie do tego faktu biskup zaprzeczył, aby miał jakieś wiadomości. Na koniec został sformułowany główny zarzut o przechowywanie broni w pałacu biskupim. Dowodem w sprawie było kilka sztuk bagnetów i karabiny, które zostały zaprezentowane. Miały być one rzekomo znalezione na strychu domu biskupiego. Pasterz najpierw podał w wątpliwość sensowność zarzutu, twierdząc, że przechowywanie broni nie licuje z posługą katolickiego biskupa. Dopuszczając natomiast teoretycznie jej obecność, zaprzeczył osobistej świadomości odnośnie do porządku rzeczy zgromadzonych na strychu. Na pytanie sądu o ewentualny udział osób trzecich $\mathrm{w}$ gromadzeniu broni $\mathrm{w}$ tym miejscu biskup podkreślił brak wiedzy na ten temat. W czasie składania zeznań siedział na fotelu i korzystał z pomocy tłumacza, którym był asesor służby więziennej sD nazwiskiem Dietrich. Przesłuchanie przed sądem trwało około godziny. Biskup został następnie odprowadzony do swojej celi, a mijając innych podsądnych pobłogosławił ich dyskretnie. Kolejne przesłuchania, z godzinną przerwą, trwały do godz. 21. Posiedzenie nie zakończyło się żadną publiczną sentencją, nikomu nie przedstawiono żadnego orzeczenia. Niemniej jednak sąd wydał wyrok. Obaj biskupi oraz jedenastu księży skazanych zostało na karę śmierci, choć informacja o tym nie została im podana ${ }^{25}$.

Warto przy tej okazji zauważyć, że wraz z wyprowadzeniem z pałacu i kurii biskupiej ich mieszkańców i urzędników Niemcy dokonali grabieży ruchomego majątku tych budynków. Wówczas to zaginęła najstarsza księga lubelskiego oficjalatu, obejmująca wpisy z lat 1426-1452, wywieziono także obrazy, meble, naczynia, a w szatach liturgicznych pochodzących z kaplicy biskupiej gestapowcy urządzili sobie prześmiewczy festyn. Budynki zajęło na stałe dowództwo Wehrmachtu ${ }^{26}$.

Wyrok niemieckiego sądu doraźnego policji wpisywał się w okupacyjny porządek prawny. Tym samym istniała formalna możliwość zastosowania prawa łaski względem skazanych. Przywilej ten przysługiwał szefowi

${ }^{25}$ Por. Z. Goliński, Diecezja w latach 1939-1944. Lublin-Oranienburg-Nowy Sącz-Lublin. Lata 1939-1945 w życiu J.E. Ks. Bpa Fulmana, wDL 22 (1945) nr 4, s. 102-104.

${ }^{26}$ Por. tamże, s. 104. 
Generalnego Gubernatorstwa Hansowi Frankowi. W istocie postanowił on ułaskawić skazanych i zamienić karę na ciężkie więzienie w obozie w Oranienburgu-Sachsenhausen. Decyzja ta zapadła w ciągu najbliższych kilku dni po procesie, najpóźniej 2 grudnia 1939 roku. Motywu jej podjęcia można się domyślać na podstawie istniejących materiałów archiwalnych - wypowiedzi samego Franka oraz korespondencji funkcjonariuszy niemieckiego Urzędu Spraw Zagranicznych. Wydaje się, że na tym etapie wojny Niemcy liczyli się z reakcją, jaką mogło wywołać stracenie katolickich biskupów. Chodziło zarówno o wydźwięk społeczny wśród ludności polskiej, jak też o międzynarodowe echo takiego aktu, zwłaszcza o przyjęcie go przez Stolicę Apostolską i możliwe skutki dyplomatyczne takiego posunięcia. Trudno natomiast podejrzewać, aby w tym czasie doszło do realnej interwencji nuncjusza apostolskiego w Berlinie w sprawie darowania życia biskupom. Czas od wyroku, zresztą nieogłoszonego publicznie, do zmiany zasądzonej kary był bardzo krótki, co w praktyce eliminuje taką hipotezę. Nie należy natomiast wykluczać dodatkowej obawy hitlerowskich władz o psychologiczny skutek, jaki egzekucja hierarchów wywołałaby wśród katolickiej części społeczeństwa niemieckiego, gdyby sprawa uległa nagłośnieniu ${ }^{27}$.

Uwolnieni od kary śmierci duchowni rozpoczęli swoją podróż do miejsca odbywania kary więzienia. O zwolnieniu z zamku poinformował ich tamtejszy komendant Paul Domnick. Wieczorem 3 grudnia bp Fulman został przewieziony autem osobowym na lubelski dworzec kolejowy, gdzie na torze oporowym stał przygotowany pociąg. Pozostali więźniowie łącznie z biskupem sufraganem zostali tam dostarczeni samochodem ciężarowym. Wszystkich umieszczono pod eskortą w przedziałach w wagonie III klasy. Zakazano rozmów, choć traktowano stosunkowo dobrze. Konwojem dowodził oficer SD. Nocny pociąg przybył do Warszawy, gdzie wagon z więźniami został doczepiony do kursowego pociągu do Berlina. Po dotarciu do stolicy Niemiec załadowano więźniów do specjalnego pojazdu więziennego. Do obozu w Oranienburgu konwój dojechał wieczorem 4 grudnia. Po odebraniu więźniom przedmiotów osobistego użytku umieszczono ich $\mathrm{w}$ celach do porannej dyspozycji. 5 grudnia nastąpiło obfitujące w upokorzenia odebranie więźniom szat kapłańskich i całości bielizny, strzyżenie, kąpiel, przydzielenie pasiaków, przymuszenie do biegu do więziennego bunkra. Już pierwszej nocy bp Fulman został zamknięty w osobnej celi

${ }^{27}$ Por. M. Wieliczko, Kontekst historyczny, art. cyt., s. 102, 107-108. 
i podlegał zupełnej separacji. Traktowany był przez dozorców więziennych bez szacunku ${ }^{28}$.

Cela bp. Fulmana oznaczona była numerem 13. Tak jak i pozostałe pomieszczenia więzienne miała 5 metrów wysokości, przy czym okno umieszczone było na wysokości 3 metrów. W celi, na cementowej podłodze znajdowało się łóżko z siennikiem i dwoma kocami - do ścielenia i przykrycia, stolik, krzesło, wiadro i naczynie na wodę. Dzień zaczynał się o godz. 6. Poranna, kilkuminutowa toaleta wiązała się z wyjściem do łazienki w kolejności numerów zamieszkiwanych cel więziennych, jednak surowo zabronione były jakiekolwiek rozmowy pomiędzy mijającymi się aresztantami. Zasadą było zachowanie absolutnej ciszy. Na śniadanie wydzielano więźniom 200-gramowy kawałek chleba i pół litra naparu ziołowego. Od godz. 11 do 12 odbywała się przechadzka na wewnętrznym dziedzińcu bunkra więziennego. Następnie podawano na obiad pół litra zupy z brukwi pastewnej i kilka gotowanych ziemniaków w łupinach. Na kolację znów wydzielano kawałek chleba, niekiedy zupę z brukwi, a dwa razy w tygodniu 130 gramów margaryny i 30 gramów kiełbasy, jak również marmoladę. O godz. 20 można było kłaść się spać. W ciągu dnia więźniowie pozostawali zupełnie bezczynni. Od końca grudnia pozwolono im korzystać z gazety „Völkischer Beobachter”, propagandowego organu prasowego hitlerowskiej partii ${ }^{29}$.

Początkowo miejsce pobytu biskupa nie było znane w diecezji. Dopiero w styczniu 1940 roku dano mu możliwość napisania listu. Jego treść podlegała formalnym rygorom obozowym, niemniej jednak dzięki niemu duchowieństwo lubelskie uzyskało informację o statusie swojego pasterza. Niewątpliwie w tym czasie o przetrzymywaniu bp. Fulmana w obozie koncentracyjnym w Oranienburgu-Sachsenhausen musiała się już dowiedzieć nuncjatura papieska w Berlinie. Można wnosić, że nie obyło się bez jej interwencji w sprawie lubelskiego pasterza. Dodatkowo, nagłaśniane przez watykańskie media wiadomości o trudnej sytuacji katolików w okupowanej Polsce, a także planowana wizyta ministra spraw zagranicznych III Rzeszy Joachima von Ribbentropa w Rzymie stanowiły co najmniej sprzyjające okoliczności, a może i bezpośrednie motywy, dla których doszło w przypadku

${ }^{28}$ Por. Z. Goliński, Diecezja w latach 1939-1944. Lublin-Oranienburg-Nowy Sącz-Lublin. Lata 1939-1945 w życiu J.E. Ks. Bpa Fulmana, wDL 22 (1945) nr 4, s. 105-107.

${ }^{29}$ Por. tenże, Bp Władysław Goral więzień Sachsenhausen, Włocławek 1946, s. 9-10; M. Wieliczko, Kontekst historyczny, art. cyt., s. 112. 
bp. Fulmana do zamiany kary surowego więzienia w Niemczech na areszt domowy na terenie Generalnego Gubernatorstwa ${ }^{30}$.

\section{Pod dachem kolegiackiej plebanii}

21 lutego 1940 roku, bez żadnych dodatkowych wyjaśnień, bp Fulman został zawiadomiony o niezwłocznym powrocie do kraju. Odebrał własne ubranie, brewiarz i rzeczy osobiste, po czym został odwieziony samochodem na dworzec berliński przez policjantów, którzy poinformowali go, że zostanie odstawiony do dyspozycji generalnego gubernatora Franka. Do Krakowa, w przedziale II klasy, konwój dotarł pociągiem przez Wrocław i Katowice. Z dworca zawieziono bp. Fulmana do Komendantury Policji i Służby Bezpieczeństwa, która mieściła się w gmachu przy ul. Pomorskiej 2. Tam biskup spędził noc. Decyzja odnośnie do jego dalszych losów już zapadła, jako że po biskupa przybył osobiście komendant policji z Nowego Sącza Heinrich Hamann, który zabrał go ze sobą. W Nowym Sączu bp Fulman został zakwaterowany w mieszkaniu pożydowskim, ale pozostał tam tylko na jedną noc. Przychylono się bowiem do jego prośby o zezwolenie na zamieszkanie na plebanii parafii kolegiackiej pw. św. Małgorzaty. Nazajutrz zatem, prawdopodobnie było to 25 lutego 1940 roku, biskupa przyjął $\mathrm{w}$ domu parafialnym - jak potem zanotowano „w atmosferze największej serdeczności” - tamtejszy proboszcz, ks. infułat Roman Mazur. Gość otrzymał do dyspozycji dwa pokoje mieszkalne, z których jeden zaadaptowany został na prywatną kaplicę pasterza. Wynikało to $\mathrm{z}$ warunków internowania, które zabraniały biskupowi udziału w publicznym kulcie w kościele. Zastosowana forma ograniczenia wolności łączyła się też początkowo z koniecznością regularnego meldowania się co drugi dzień w nowosądeckiej placówce niemieckiej żandarmerii. Jednak po trzech miesiącach, zapewne $\mathrm{z}$ uwagi na subordynację więźnia oraz jego podeszły wiek, obowiązek ten został zniesiony ${ }^{31}$.

Pobyt biskupa na plebanii w Nowym Sączu był dla niego osobiście - mimo wszelkich dolegliwości związanych z zaistniałą sytuacją - rozwiązaniem obiektywnie szczęśliwym, zwłaszcza w kontekście losów bp. Władysława

${ }^{30}$ Por. M. Wieliczko, Kontekst historyczny, art. cyt., s. 108-113.

${ }^{31}$ Por. Z. Goliński, Diecezja w latach 1939-1944. Lublin-Oranienburg-Nowy Sącz-Lublin. Lata 1939-1945 w życiu J.E. Ks. Bpa Fulmana, wDL 22 (1945) nr 4, s. 107; M. Wieliczko, Kontekst historyczny, art. cyt., s. 113-115. 
Gorala czy pozostałych księży skazanych wraz z pasterzem na karę śmierci. Biskup pomocniczy pozostał w Oranienburgu, w całkowitej izolacji niemal do końca wojny, by umrzeć w bunkrze więziennym wiosną 1945 roku. Natomiast spośród jedenastu księży skazanych wraz z biskupami jeden zmarł jeszcze w Oranienburgu, a pozostali trafili 14 grudnia 1940 roku do obozu koncentracyjnego w Dachau, gdzie w trudnych obozowych warunkach straciło życie kolejnych sześciu spośród nich ${ }^{32}$.

\section{Administrowanie diecezja}

Względnie korzystna odmiana losu pasterza miała porządkujący wpływ na funkcjonowanie lubelskiej diecezji. Niemcy nie utrudniali bowiem biskupowi pozostającemu w miejscu internowania utrzymywania kontaktów z Lubelszczyzną. Nawiązano je właśnie w tym czasie, gdy na wiosnę 1940 roku, ze względu na wizytę Ribbentropa w Watykanie, hitlerowcy doprowadzili do ujawnienia się pozostającego dotąd w ukryciu, mianowanego w warunkach okupacyjnych jesienią 1939 roku, wikariusza generalnego diecezji lubelskiej, ks. Zygmunta Surdackiego i pozwolili na reaktywowanie kurii w skromnych warunkach rektoratu kościoła pw. Wniebowzięcia NMP Zwycięskiej w Lublinie ${ }^{33}$. Działania te, stanowiące niezbędne minimum dla częściowej przynajmniej normalizacji życia kościelnego w diecezji, były o tyle istotne, że utrudniały na przyszłość narzucenie niekanonicznych rozwiązań, do których chętnie skłaniali się Niemcy. Warto bowiem wspomnieć, że jeszcze w maju 1940 roku zaproponowali oni sufraganowi włocławskiemu bp. Michałowi Kozalowi, więzionemu wówczas w klasztorze w Lądzie, zarządzanie diecezją lubelską $\mathrm{w}$ zamian za uwolnienie go $\mathrm{z}$ aresztu. Propozycja ta została jednak odrzucona ${ }^{34}$.

Forma kierowania diecezją przez internowanego biskupa opierała się na wymianie korespondencji, jak również na osobistych spotkaniach z często odwiedzającymi Nowy Sącz urzędnikami kurialnymi i innymi kapłanami. Plebania kolegiacka dawała pod tym względem znaczne możliwości, jako

${ }^{32}$ Por. Z. Goliński, Diecezja w latach 1939-1944. Lublin-Oranienburg-Nowy Sącz-Lublin. Lata 1939-1945 w życiu J.E. Ks. Bpa Fulmana, wDL 22 (1945) nr 4, s. 108.

${ }_{33}$ Por. J. R. Marczewski, Surdacki Zygmunt, [w:] Polski słownik biograficzny, t. 45, red. A. Romanowski, Warszawa-Kraków 2008, s. 637.

${ }^{34}$ Por. Z. Goliński, Diecezja w latach 1939-1944. Lublin-Oranienburg-Nowy Sącz-Lublin. Lata 1939-1945 w życiu J.E. Ks. Bpa Fulmana, wDL 23 (1946) nr 1, s. 23-24. 
że miejscowy proboszcz rozwinął w okresie okupacji szeroką działalność dobroczynną. Czyniło to $\mathrm{z}$ domu parafialnego miejsce pracy i częstych wizyt bardzo wielu osób, wśród których przybywającym do Nowego Sącza emisariuszom diecezji łatwiej było się ukryć, unikając potencjalnie niebezpiecznych kontaktów $\mathrm{z}$ okupantami ${ }^{35}$. Co równie ważne, jak opisywał biograf pasterza, „plebania i jej gospodarz serdeczną gościnnością darzyli nie tylko księdza biskupa, lecz i jego coraz to liczniejszych gości z Lublina, którzy dążyli do osoby pasterza bądź w sprawach urzędowych, bądź z potrzeby serca" ${ }^{36}$.

Najwcześniejsze ślady wymiany listów i przyjmowania wizyt z diecezji pochodzą już z pierwszych dni pobytu bp. Fulmana w Nowym Sączu. Mianowicie 7 marca 1940 roku pisał on do ks. Józefa Scipio del Campo, proboszcza w Kraśniku, a za jego pośrednictwem do pozostałych kapłanów tego dekanatu, że odwiedziło go już dwóch księży z Lublina. Zachęcał do gorliwej pracy duszpasterskiej, materialnej pamięci o kurii i troski o ubogich kapłanów ${ }^{37}$.

Najwcześniejsza zachowana korespondencja biskupa z ks. Surdackim, wikariuszem generalnym, była datowana 17 maja 1940 roku. List utrzymany został w osobistym, niezwykle życzliwym tonie. Dodatkowo jego treść stanowiła potwierdzenie faktu odwiedzania pasterza przez ks. Surdackiego. Biskup pisał bowiem, że został już poinformowany o jego planowanym przybyciu do Nowego Sącza. Wyrażał nadzieję, że przy tej okazji uda się im omówić szczegółowiej pewne istotne kwestie ${ }^{38}$.

Ze szczątkowo zachowanej korespondencji biskupa z wikariuszem generalnym i innymi urzędnikami lubelskiej kurii, którą strony wymieniały na przestrzeni 1940 roku, można wyłowić kilka wątków stanowiących przedmiot zainteresowania pasterza. Tak więc biskup angażował się w problematykę obsady stanowisk administracyjnych i duszpasterskich. Przykładowo 10 sierpnia 1940 roku nominował ks. Piotra Stopniaka na zastępcę wikariusza generalnego vicario absente vel impedito ${ }^{39}$. W skazał osoby, które z ramienia kurii, ze względu na biegłą znajomość języka niemieckiego miały stanowić

35 Por. M. Wieliczko, Kontekst historyczny, art. cyt., s. 115-116.

${ }^{36}$ Z. Goliński, Diecezja w latach 1939-1944. Lublin-Oranienburg-Nowy Sacz-Lublin. Lata 1939-1945 w życiu J.E. Ks. Bpa Fulmana, wDL 22 (1945) nr 4, s. 107.

37 Por. AAL, Dz III 1, Biskup Marian Leon Fulman - posługa w diecezji w okresie 1944-1945, k. 2 r.

${ }^{38}$ Por. AAL, Rep 60 IIb S124, Akta osobowe ks. Zygmunta Surdackiego, k. 11r.

39 Por. AAL, Rep 60 IIb S174, Akta osobowe ks. Piotra Stopniaka, k. 33r. 
zespół do niezbędnych kontaktów z okupantami w sprawach kościelnych. Zdaniem pasterza - wyrażonym 9 sierpnia 1940 roku w liście do wikariusza generalnego - powinni to być księża Bogusław Waczyński i Henryk Sekrec$\mathrm{ki}^{40}$. Ponadto pasterz zlecił reaktywowanie sądu biskupiego w zakresie dotyczącym spraw małżeńskich. Wyrażał również przypuszczenie, że sąd lubelski mógłby pełnić rolę sądu drugiej instancji dla archidiecezji warszawskiej. Niepokoił się wszakże o właściwą obsadę stanowisk, zwłaszcza o kwalifikacje notariusza ${ }^{41}$. Mianował oficjałem ks. Zenona Kwieka ${ }^{42}$, notariuszem ks. Pawła Pałkę ${ }^{43}$, sędzią ks. Piotra Stopniaka ${ }^{44}$ i zezwolił na ustanowienie przy sądzie adwokata ${ }^{45}$. Zatroszczył się także o powołanie administratora parafii katedralnej w osobie ks. Piotra Stopniaka ${ }^{46}$ oraz rektora kościoła pw. Wniebowzięcia NMP Zwycięskiej w Lublinie, którym został ks. Henryk Sekrecki ${ }^{47}$.

Biskup zajął się także problemem finansowania kurii. 24 października 1940 roku poinformował ks. Surdackiego, że polecił Bankowi Rolnemu w Lublinie, aby wypłacał kurii 100 zł tygodniowo z posiadanego przez nią rachunku bieżącego. Do odbierania środków wyznaczył ks. Pawła Dziubińskiego i ks. Jana Poddębniaka ${ }^{48}$.

Pasterz został także zmuszony podjąć wątek napięć międzywyznaniowych w kontekście faworyzowania prawosławia przez okupantów. Sygnalizował w sekrecie swoje stanowisko odnośnie do rozwiązania problemu kościoła NMP w Chełmie, który został przez Niemców przekazany wspólnocie prawosławnej ${ }^{49}$.

Co ciekawe, biskup był przeciwnikiem wznawiania urzędowego pisma „Wiadomości Diecezjalne Lubelskie”, co planował uczynić ks. Surdacki.

$4^{\circ}$ Por. AAL, Rep 60 IIb S124, k. 15r.

${ }^{41}$ Por. tamże, k. 11v-12r.

${ }^{42}$ Por. K. A. Kołodziejczyk, Rzadca wierny i roztropny. Ksiadz Zenon Tymoteusz Kwiek (1868-1949), [w:] W Duchu i prawdzie. Wybrane sylwetki Kościoła lubelskiego (1805-2005), red. H. Misztal, Lublin 2005, s. 402.

${ }^{43}$ Por. T. Kądziołka, Wielki wychowawca kapłanów. Ksiądz Paweł Pałka (1904-1992), [w:] W Duchu i prawdzie. Wybrane sylwetki Kościoła lubelskiego (1805-2005), dz. cyt., s. 445.

${ }^{44}$ Por. AAL, Rep 60 IIb S174, k. 3or, 32r, 4or, 41r.

45 Por. AAL, Rep 60 irb S124, k. 7r, 14 r.

${ }^{46}$ Por. tamże, k. 13r; Rep 60 IIb S174, k. 29r, 31r.

47 Por. AAL, Rep 60 IIb S124, k. 15r.

${ }^{48}$ Por. tamże, k. 16r-v.

49 Por. tamże, k. 12v. 
Pasterz wyraził wolę, aby porozumiewanie się kurii z duszpasterzami odbywało się zwykłą drogą pocztową, a nie przez słowo drukowane ${ }^{50}$.

Niewątpliwie zestawione tu przykłady stanowią świadectwo realnego oddziaływania biskupa na porządek życia w diecezji w pierwszym okresie jego internowania, zwłaszcza w zakresie kurialno-administracyjnym. Skądinąd trzeba także zdawać sobie sprawę $\mathrm{z}$ faktu, że pozostawanie bp. Fulmana poza diecezją stanowiło mimo wszystko poważną komplikację w wykonywaniu władzy pasterskiej. Ostatecznie zaciążyło to fatalnie na relacjach z ks. Surdackim, którego zaczęto niesłusznie oskarżać przed biskupem o autorytaryzm i próbę usamodzielnienia się w rządach diecezją bez oglądania się na pasterza, a nawet o prowadzenie działań na rzecz ustanowienia w Lublinie administratury apostolskiej. Zapewne wchodziła tu w grę niechęć niektórych osób do ks. Surdackiego - kapłana ubolewającego nad zaniedbaniami w zakresie duszpasterstwa i pomocy charytatywnej, a w konsekwencji, na gruncie udzielonej mu władzy, starającego się zdecydowanie egzekwować lojalność duchowieństwa wobec etosu kapłańskiego i narodowego. Jak wynikało z relacji abp. Stanisława Galla, stan rzeczy, w którym na miejscu w Lublinie, $\mathrm{w}$ czasie internowania pasterza, aktywnie działał wikariusz generalny, aprobowała w pełni Stolica Apostolska ${ }^{51}$. Rzym został zresztą poinformowany o takim właśnie sposobie zarządzania diecezją przez samego bp. Fulmana listem datowanym w Nowym Sączu 10 września 1940 roku, przesłanym do nuncjusza w Berlinie. Pasterz powiadamiał w nim o swoim internowaniu, ale też o częstych wizytach wikariusza generalnego, dzięki któremu miał możliwość dowiadywania się o sprawach diecezji i kierowania nimi ${ }^{52}$.

Ostatecznie jednak, na skutek nasilających się intryg personalnych, 31 października 1940 roku ks. Surdacki został pozbawiony przez biskupa funkcji wikariusza generalnego ${ }^{53}$. W tym samym dniu została wystawiona nominacja dla jego następcy - ks. Józefa Kruszyńskiego ${ }^{54}$. Dwa tygodnie później ks. Piotr Stopniak, zastępca wikariusza generalnego, otrzymał list, w którym bp Fulman polecił mu odebrać akta urzędowe od ks. Surdackiego i przekazać je ks. Kruszyńskiemu ${ }^{55}$. Ten ostatni udał się w tym czasie do Nowego Sącza,

5o Por. tamże, k. 11r-v.

${ }^{51}$ Por. J. R. Marczewski, Surdacki Zygmunt, art. cyt., s. 637.

${ }^{52}$ Por. AAL, Rep 60 iıb F15, Akta osobowe ks. bp. Mariana Leona Fulmana, k. 10 r.

53 Por. AAL, Rep 60 IIb S124, k. 9r.

${ }^{54}$ Por. AAL, Rep 6o IIb K111, Akta osobowe ks. Józefa Kruszyńskiego, k. 3r.

55 Por. AAL, Rep 60 IIb S174, k. 34r-v. 
gdzie wobec biskupa, w dniu 16 listopada, złożył wyznanie wiary przewidziane przy obejmowaniu urzędu ${ }^{56}$. Wykonanie rozporządzeń biskupich i cały proces przejmowania władzy zajęły jeszcze kilka dni, tak że faktyczne ustąpienie ks. Surdackiego można datować na 21 listopada 1940 roku $^{57}$.

Zachowały się interesujące dokumenty, w których bp Fulman określił zakres władzy ks. Kruszyńskiego, jako wikariusza generalnego. Upoważnił go najpierw, w dniu 4 grudnia 1940 roku, co uszczegółowił jeszcze 28 marca 1941 roku, do ograniczenia wszystkich uprawnień dziekańskich, jakie księża ci nabyli poza porządkiem prawnym wynikającym z kanonów kodeksu i statutów synodu lubelskiego. W konsekwencji miało to prowadzić do odzyskania pełnej kontroli administracyjnej nad diecezją przez kurię biskupią. Wyjątek był dopuszczony tylko w tych sytuacjach, w których kontakt $z$ kurią był przerwany, zwłaszcza wskutek działań wojennych ${ }^{58}$. Tego samego dnia, tj. 4 grudnia, biskup upoważnił też ks. Kruszyńskiego do wyznaczania, zawieszania i odwoływania ze stanowisk administratorów parafii, rektorów kościołów, wikariuszy parafialnych i prefektów szkolnych ${ }^{59}$. Wreszcie, 10 maja 1941 roku, pasterz udzielił ks. Kruszyńskiemu prawa załatwiania podczas jego nieobecności w diecezji wszystkich spraw kościelnego zarządu diecezjalnego, za wyjątkiem nominowania członków lubelskiej kapituły katedralnej i zamojskiej kapituły kolegiackiej, nominowania proboszczów nieusuwalnych i alienacji dóbr kościelnych ${ }^{60}$.

Te daleko idące uprawnienia nie oznaczały jednak, że bp Fulman wycofał się na dalszy czas internowania w Nowym Sączu z aktywnego wpływania na kształt polityki personalnej i administracyjnej w diecezji lubelskiej. Przeciwnie. W zachowanych materiałach źródłowych można odnaleźć cały szereg dokumentów wskazujących na żywe zaangażowanie biskupa w tych obszarach.

Biskup Fulman, pomimo przekazania kwestii obsady parafii w ręce wikariusza generalnego, nie poniechał swojego zainteresowania tymi sprawami. Tak więc 27 marca 1942 roku mianował ks. Jana Poddębniaka proboszczem w Krężnicy Jarej ${ }^{61}$. Z kolei 1 września 1942 roku dopytywał się listownie

\footnotetext{
${ }^{56}$ Por. AAL, Rep 60 IIb K111, k. 4r.

${ }^{57}$ Por. J. R. Marczewski, Surdacki Zygmunt, art. cyt., s. 637.

${ }^{58}$ Por. AAL, Rep 60 IIb K111, k. 5r.

59 Por. tamże, k. 6r.

${ }^{60}$ Por. tamże, k. 1 r.

${ }^{61}$ Por. AAL, Rep 60 IIb S174, k. 37r.
} 
ks. Kruszyńskiego o plany odnośnie do parafii Kamionka, Goraj i Wielącza. W przypadku tej ostatniej podkreślał, że źle jej służyły częste zamiany proboszczowskie $^{62}$. Z kolei 9 listopada tego samego roku powiadomił kurię biskupią, że postanowił, aby ks. Józef Barszczewski pozostał w Bychawie $\mathrm{w}$ charakterze administratora. List ten pozwala wejrzeć w sposoby działania biskupa i kurii, jako że miała ona w tym wypadku przyjąć po prostu do wiadomości decyzję biskupa i zawiadomić bezpośrednio zainteresowanego kapłana ${ }^{63}$.

Pasterz był na bieżąco informowany także o planach zmiany granic parafii w Podgórzu. W tym wypadku decyzja na odległość była trudniejsza. Stąd też 5 maja 1941 roku biskup pisał do ks. Kruszyńskiego o swoim niezdecydowaniu. Polecał mu przy rozstrzygnięciu polegać na opinii dziekana, proboszcza i parafian ${ }^{64}$. Pięć dni później wypowiedział się natomiast kategoryczniej odnośnie do urządzenia plebanii w Podgórzu ${ }^{65}$.

Biskup nadal dbał o sąd biskupi. Pod koniec 1942 roku dopuścił do współpracy z nim kolejnego adwokata, napominając zarazem niechętnych tej decyzji księży ${ }^{66}$.

Odnośnie do składu kurii biskupiej 10 maja 1941 roku pasterz polecał wikariuszowi generalnemu, aby powstrzymał się od powołania ks. Henryka Sekreckiego do pracy w tej instytucji i pozostawił jego związek z kurią na poziomie niesformalizowanym ${ }^{67}$. Na wniosek biskupa wikariusz generalny mianował natomiast 1 kwietnia 1942 roku sekretarzem kurii ks. Jana Poddębniaka ${ }^{68}$, którego następnie 18 maja 1943 roku ustanowił jej notariuszem ${ }^{69}$. 28 marca 1941 roku bp Fulman ustalił porządek zastępowania wikariusza generalnego w przypadku, gdyby ten nie mógł wykonywać swych obowiązków. Zastępcami zostali zatem księża: Piotr Stopniak, Paweł Dziubiński i Feliks Szeleźniak. Ten ostatni został też mianowany radcą kurii biskupiej ${ }^{70}$.

${ }^{62}$ Por. AAL, Rep 60 IIb F16, Akta osobowe ks. bp. Mariana Leona Fulmana, k. 64v.

${ }^{63}$ Por. tamże, k. 66r.

${ }^{64}$ Por. AAL, Rep 6o irb K111, k. 9r.

${ }^{65}$ Por. tamże, k. 11v.

${ }^{66}$ Por. AAL, Rep 60 IIb F16, k. 64r, 65r; Rep 60 IIb P102, Akta osobowe ks. Jana Poddębniaka, k. 2 r.

${ }^{67}$ Por. AAL, Rep 6o irb K111, k. 11r.

${ }^{68}$ Por. AAL, Rep 6o irb P102, k. 3r.

${ }^{69}$ Por. tamże, k. 1r.

${ }^{70}$ Por. AAL, Rep 60 iıb K111, k. 7r. 
W kontekście zbliżającego się frontu wojennego bp Fulman postanowił raz jeszcze upewnić się co do zabezpieczenia ciągłości władzy administracyjnej w diecezji. Dlatego 13 czerwca 1944 roku poinformował ks. Kruszyńskiego listem z Nowego Sącza o wyznaczeniu czterech zastępców i zarazem następców wikariusza generalnego ipso absente vel impedito. Mieli to być w kolejności księża: Stopniak, Dziubiński, Szeleźniak i Goliński. Doraźnie otrzymywali oni także stanowisko radców kurii ${ }^{11}$.

Pasterz interesował się też wydawaniem diecezjalnego kalendarza liturgicznego. Poinformowany o niezamieszczeniu w nim pewnych oficjów zachęcał odpowiedzialnego za to zaniedbanie ks. Zenona Kwieka, aby dobrał sobie do pomocy w tym dziele ks. Karola Konopkę ${ }^{72}$.

Biskup nie zapominał też o cierpieniach księży. Interesował się doraźnym stanem zdrowia niektórych, jak choćby przedłużającą się chorobą podeszłego już w latach ks. Zenona Kwieka ${ }^{73}$ czy długotrwałym przeziębieniem ks. Piotra Stopniaka ${ }^{74}$. Bolał nad losem swych niedawnych najbliższych współpracowników. Jak twierdził w listach, dotknęła go śmierć poprzedniego wikariusza generalnego, ks. Zygmunta Surdackiego ${ }^{75}$, a także ks. Zdzisława Ochalskiego, przedwojennego kanclerza kurii. Rodzicom ks. Ochalskiego wysłał pocztą swoje kondolencje $\mathrm{e}^{76}$.

Pośród lubelskich duchownych, z którymi biskup utrzymywał kontakt wyraźnie da się zauważyć kilka grup. Przede wszystkim byli to, co zrozumiałe, najwyżsi urzędnicy instytucji diecezjalnych - najpierw ks. Surdacki, potem ks. Kruszyński i ks. Stopniak. Nie brakowało kontaktów doraźnych, nieurzędowych, quasi-towarzyskich lub też formalnych, ale sporadycznych, jak te z księżmi: Witoldem Korsakiem, Florianem Krasuskim, Józefem Scipio del Campo, Zenonem Kwiekiem, Stanisławem Witkowskim. Wreszcie wydaje się, że osobną kategorię stanowiło trzech księży, których biskup szczególnie cenił, z którymi częściej korespondował i których wizyty chętnie przyjmował. Działo się tak zapewne z powodu ich młodszego wieku, większej operatywności i zdolności świadczenia biskupowi różnorakich

\footnotetext{
${ }_{71}$ Por. AAL, Rep 60 IIb S174, k. 38r.

${ }_{72}$ Por. AAL, Rep 6o irb F16, k. 68r-v.

${ }^{73}$ Por. tamże, k. 68r.

74 Por. tamże, k. 6ov.

75 Por. AAL, Rep 6o IIb K111, k. 9r.

${ }^{76}$ Por. AAL, Rep 60 iIb F16, k. 64r.
} 
posług. Byli to księża: Paweł Dziubiński, Jan Poddębniak i Zdzisław Goliński. Przy czym ten ostatni, choć często konsultowany, bodaj w najmniejszym stopniu $\mathrm{z}$ wymienionego grona pomagał spełniać proste zadania życiowe, w których celowali dwaj pierwsi. Przenosili oni korespondencję od biskupa do wikariusza generalnego i innych urzędników, przekazywali polecenia ustne i dopowiadali to, czego w listach nie należało zawierać $c^{77}$. Byli też chyba najczęstszymi gośćmi z Lublina na plebanii kolegiackiej w Nowym Sączu. Niewątpliwie większym zaufaniem w sprawach osobistych biskup darzył jednak ks. Dziubińskiego. Wniosek taki nasuwa się choćby z lektury testamentu biskupiego. Pasterz ustanowił jego wykonawcą właśnie ks. Dziubińskiego ${ }^{78}$. Co więcej, 24 marca 1944 roku, w obliczu utraty nadziei na przeniesienie się do diecezji lubelskiej, a także ze względu na pogarszające się samopoczucie i słabnące zdrowie bp Fulman powołał ks. Dziubińskiego na swojego kapelana. Zwolnił go z obowiązku rezydowania przy kościele pw. Nawrócenia św. Pawła w Lublinie i zlecił mu stałe pozostawanie w Nowym Sączu. Koszty pobytu ks. Dziubińskiego miała pokryć lubelska kuria biskupia ${ }^{79}$.

\section{Udzielanie święceń}

Ciekawym fenomenem związanym $\mathrm{z}$ internowaniem bp. Fulmana w Nowym Sączu było udzielanie przez niego święceń w zaimprowizowanej kaplicy na plebanii kościoła kolegiackiego. Następstwem wkroczenia Niemców do Polski w dobie drugiej wojny światowej była polityka antykościelna o różnym stopniu opresyjności w poszczególnych rejonach kraju i o zmiennym nasileniu w zależności od upływającego czasu okupacji. W przypadku diecezji lubelskiej skutkowała ona m.in. zamknięciem seminarium duchownego, które nie mogło podjąć swojej działalności począwszy od jesieni 1939 do stycznia 1942 roku. Rzutowało to na kwestię przygotowania kadr miejscowego duchowieństwa, uszczuplonego nie tylko wskutek przyczyn naturalnych, ale także na drodze dokonywanych przez okupantów aresztowań i egzekucji. W przewidywaniu trudnej sytuacji, jeszcze we wrześniu 1939 roku, w pierwszych dniach po zajęciu Lublina przez Niemców, na polecenie bp. Fulmana doszło do przyspieszonych święceń diakonatu

\footnotetext{
77 Por. tamże, k. 50v, 58r, 62r, 69r, 96r; Rep 6o IIb K111, k. 9r, 10 .

${ }^{78}$ Por. AAL, Rep 6o inb F16, k. 71r.

79 Por. tamże, k. 99r.
} 
i prezbiteratu w seminaryjnym kościele pw. Przemienienia Pańskiego. Udzielił ich trzem kandydatom bp Władysław Goral ${ }^{80}$. Po aresztowaniu i wywiezieniu z Lublina obu biskupów, zapewne nie bez porozumienia się z pasterzem, internowanym już wówczas w Nowym Sączu, dwukrotnie, tj. w marcu i kwietniu 1940 roku, udało się wyświęcić w Lublinie następnych alumnów z przedwojennych roczników. Był to niewątpliwie skutek wspominanego zezwolenia Niemców na ujawnienie się i reorganizację kurii biskupiej. W tych okolicznościach bowiem wikariusz generalny ks. Surdacki, oficjalnie - samochodem Polskiego Czerwonego Krzyża - przywiózł z Warszawy do Lublina sufragana pińskiego bp. Karola Niemirę, który udzielał wskazanym klerykom święceń diakonatu i prezbiteratu w rektoralnym kościele pw. św. Jozafata przy ul. Zielonej ${ }^{81}$. Warto dodać, że święcenia te odbywały się przy zamkniętych drzwiach świątyni ${ }^{82}$. Łącznie zostało wówczas księżmi 16 kandydatów ${ }^{83}$. Jeden $\mathrm{z}$ wyświęconych wtedy diakonów

${ }^{80}$ Por. AAL, Rep 60 IIb F27, Akta osobowe ks. Józefa Frankowskiego, bez paginacji, Deklaracja przed przyjęciem święceń, 24 września 1939 r. z adnotacją bp. W. Gorala; Rep 60 IIb G73, Akta osobowe ks. Feliksa Gąski, bez paginacji, Deklaracja przed przyjęciem święceń, 24 września 1939 r. z adnotacją bp. W. Gorala; Rep 60 Irb M87, Akta osobowe ks. Stefana Młynarczyka, bez paginacji, Kopia dokumentu zezwalającego na udzielenie święceń prezbiteratu z dopiskiem bp. W. Gorala o ich udzieleniu, 24 września 1939 r.; Rep 60 IIb G57, Notatnik z kazaniami, s. $117-118$.

${ }^{81}$ Por. Z. Starnawski, Martyrologium duchowieństwa diecezji lubelskiej, dz. cyt., s. 20; J. Ziółek, Losy seminariów duchownych $i$ wydziałów teologicznych $w$ latach okupacji hitlerowskiej $w$ Polsce, „Studia Płockie” 13 (1985), s. 8 o.

${ }^{82}$ Por. AAL, Rep 6o IIb S194, Akta osobowe ks. Hieronima Świcia, bez paginacji, Curriculum vitae.

${ }^{83}$ Por. AAL, Rep 60 IIb D6o, Akta osobowe ks. Michała Dudkowskiego, bez paginacji, Zaświadczenie o kwalifikacjach do nauczania religii, 23 stycznia 1957 r.; Rep 60 IIb F24, Akta osobowe ks. Czesława Furtaka, bez paginacji, Karta informacyjna; Rep 60 IIb K138, Akta osobowe ks. Władysława Kłosa, bez paginacji, Karta informacyjna; Rep 60 IIb K135, Akta osobowe ks. Wacława Kosmali, bez paginacji, Zaświadczenie o kwalifikacjach do nauczania religii, 28 lutego 1957 r.; Rep 60 IIb K159, Akta osobowe ks. Józefa Kuńca, bez paginacji, Karta informacyjna; Rep 60 IIb L28, Akta osobowe ks. Jana Lewczyńskiego, bez paginacji, Zaświadczenie o kwalifikacjach do nauczania religii, 10 marca 1951 r.; Rep 60 IIb M98, Akta osobowe ks. Bolesława Mazurka, bez paginacji, Karta informacyjna; Rep 60 IIb M106, Akta osobowe ks. Piotra Mazurka, bez paginacji, Karta informacyjna; Rep 6o IIb M114, Akta osobowe ks. Mariana Mroczka, bez paginacji, Karta informacyjna; Rep 60 IIb R30, Akta osobowe ks. Jana Rolli, bez paginacji, Prośba do bp. M. L. Fulmana o udzielenie święceń prezbiteratu, 13 kwietnia 1940 r.; Rep 60 IIb R33, Akta osobowe ks. Tomasza Ruska, bez paginacji, Karta informacyjna; Rep 60 IIb S153, Akta osobowe ks. Wojciecha Sikory, bez paginacji, Życiorys; Rep 60 IIb S184, 
przyjął święcenia kapłańskie dopiero jesienią 1940 roku, przy czym trudno ustalić gdzie i z czyich $\mathrm{rąk}^{84}$. W każdym razie $\mathrm{w}$ ten sposób wyczerpały się możliwości związane z prezentowaniem do święceń tych alumnów, którzy jeszcze przed wojną otrzymali wystarczającą formację.

Ze względu na stosunkowo dogodne warunki, jakie towarzyszyły pobytowi bp. Fulmana w Nowym Sączu, dla całego środowiska kościelnego diecezji lubelskiej stało się jasne, że zaistniała także możliwość udzielania święceń przez samego pasterza, oczywiście w miejscu jego internowania, w sposób niejawny, właściwie sekretny, opisany obrazowo po latach przez jednego z tak wyświęconych kapłanów jako „przyjmowanie na sposób katakumbowy ornatu do odprawiania Mszy św." ${ }^{85}$. Zasadniczym wyzwaniem stało się więc wówczas przygotowanie do sakramentu kapłaństwa tych kleryków, którzy byli już nieco zaawansowani w procesie studiów seminaryjnych, ale nie w takim stopniu, aby można ich było łatwo promować. Chętnym zalecono zatem indywidualne przygotowanie zadanego materiału i zdawanie egzaminów u wyznaczonych profesorów, rozproszonych w parafiach Lublina i Lubelszczyzny ${ }^{86}$. Wydaje się, że pierwsza grupa wyświęconych przez bp. Fulmana w prywatnej kaplicy na plebanii w Nowym Sączu otrzymała święcenia prezbiteratu 15 czerwca 1941 roku. Liczyła ona czterech alumnów. Byli to: Aleksander Furmanik, Stefan Kędzierski, Władysław Krześniak oraz Hieronim Świć ${ }^{87}$. 6 lipca święcony był

Akta osobowe ks. Bolesława Świsia, bez paginacji, Karta informacyjna; Rep 6o IIb W78, Akta osobowe ks. Czesława Wiślińskiego, bez paginacji, Karta informacyjna; Rep 60 Irb Z66, Akta osobowe ks. Longina Ziarka, bez paginacji, Karta informacyjna; P. Tarnowski, Śp. Ks. Piotr Gąder (1914-1993), „Kronika Diecezji Sandomierskiej” 87 (1994) nr 3-4, s. 190; Spis kościołów i duchowieństwa diecezji lubelskiej, Lublin 1948, s. 227.

${ }^{84}$ Por. AAL, Rep 6o IIb R36, Akta osobowe ks. Stefana Roszkowskiego, bez paginacji, Zaświadczenie o kwalifikacjach do nauczania religii, 12 stycznia $1950 \mathrm{r}$.

${ }^{85}$ AAL, Rep 60 IIb N31, Akta osobowe ks. Jana Nieróbcy, bez paginacji, Testament, 1 stycznia $1992 \mathrm{r}$.

${ }^{86}$ Por. Z. Starnawski, Martyrologium duchowieństwa diecezji lubelskiej, s. 20; J. Ziółek, Losy seminariów duchownych, art. cyt., s. 8 o.

${ }^{87}$ Por. AAL, Rep 60 IIb F28, Akta osobowe ks. Aleksandra Furmanika, bez paginacji, Życiorys, 27 stycznia 1947 r.; Rep 60 IIb K149, Akta osobowe ks. Stefana Kędzierskiego, bez paginacji, Prośba do bp. M. L. Fulmana o udzielenie święceń prezbiteratu, 10 czerwca 1941 r.; Rep 60 IIb K129, Akta osobowe ks. Władysława Krześniaka, bez paginacji, Deklaracja przed przyjęciem święceń prezbiteratu, 12 czerwca 1941 r.; Rep 6o Irb S194, Akta osobowe ks. Hieronima Świcia, bez paginacji, Curriculum vitae. 
Jan Meger ${ }^{88}$. W następnych miesiącach zostali wyświęceni kolejni kandydaci. 14 września 1941 roku święcenia kapłańskie w Nowym Sączu otrzymali Stefan Brewiński, Stanisław Malikowski i Franciszek Surtel ${ }^{89}$. Natomiast 14 grudnia zostali wyświęceni Wacław Chromiak, Feliks Kępski, Jan Nieróbca, Kazimierz Truchel i Józef Walczak ${ }^{90}$.

Alumni dojeżdżali do Nowego Sącza pociągiem pospiesznym relacji Chełm-Kraków przez Rozwadów, wsiadali na stacji w Lublinie o godz. 7 rano. Podróż trwała około 11 godzin, tak więc w Nowym Sączu pojawiali się wieczorem, mniej więcej o godz. 18, by następnego dnia rano przystąpić do święceń. Oficjalną prośbę o święcenia i konieczne przy tej okazji zobowiązania składali jeszcze w Lublinie. Pasterz zwalniał przybyłych od interstycji - wymaganych prawem okresów przerwy pomiędzy poszczególnymi stopniami święceń - i dzień po dniu udzielał subdiakonatu, diakonatu i prezbiteratu.

Bodaj już te pierwsze wizyty ujawniły problem o charakterze logistycznym - trudności z zapewnieniem odpowiedniej liczby miejsc noclegowych na plebanii. Niezręcznie było także obciążać lokalnych duszpasterzy zadaniem dopilnowywania przybyszów z Lublina i opieką nad nimi. Stąd też bp Fulman, nauczony pierwszymi doświadczeniami, pisał do ks. Piotra Stopniaka 4 listopada 1941 roku: „Gdyby jeszcze mieli przybyć klerycy w tym roku do Nowego Sącza celem uzyskania ode mnie święceń, to muszą stanąć w hotelu, bo na plebanii brak miejsca i brak opału. Musiałby ktoś z nimi

${ }^{88}$ Por. Archiwum Kurii Biskupiej Diecezji Koszalińsko-Kołobrzeskiej, Akta osobowe ks. Jana Megera, bez paginacji, Życiorys, 25 maja 1959 r.

${ }^{89}$ Por. AAL, Rep 60 IIb M116, Akta osobowe ks. Stanisława Malikowskiego, bez paginacji, Życiorys, 23 grudnia 1946 r.; Rep 60 IIb S189, Akta osobowe ks. Franciszka Surtela, bez paginacji, Prośba do bp. M. L. Fulmana o udzielenie święceń prezbiteratu, 10 września 1941 r.; L. Marianowski, Ksiądz kanonik Stefan Brewiński (1911-1995), „Kronika Diecezji Sandomierskiej" 89 (1996) nr 3-4, s. 160.

$9^{\circ}$ Por. AAL, Rep 60 irb C51, Akta osobowe ks. Wacława Chromiaka, bez paginacji, Prośba do bp. M. L. Fulmana o udzielenie święceń subdiakonatu, diakonatu i prezbiteratu, 24 listopada 1941 r.; Rep 60 Irb K174, Akta osobowe ks. Feliksa Kępskiego, bez paginacji, Prośba do bp. M. L. Fulmana o udzielenie święceń subdiakonatu, diakonatu i prezbiteratu, 10 grudnia 1941 r.; Rep 60 iıb N31, Akta osobowe ks. Jana Nieróbcy, bez paginacji, Prośba do bp. M. L. Fulmana o udzielenie święceń subdiakonatu, diakonatu i prezbiteratu, 24 listopada 1941 r.; Rep 60 IIb W66, Akta osobowe ks. Józefa Walczaka, bez paginacji, Poświadczenie o kwalifikacjach do nauczania religii, 24 stycznia 1957 r.; Schematyzm diecezji zamojsko-lubaczowskiej, oprac. F. Greniuk, L. Cybruch, Zamość 1995, s. 110. 
przyjechać i ich pobytem się zająć, gdyż ja sam nie dam rady i tutejsi księża pomocy nie dadzą"91.

W tym samym czasie, gdy wyżej wspominani alumni, potajemnie finalizując formację teologiczną, przyjmowali święcenia kapłańskie, pojawiła się realna szansa na oficjalne reaktywowanie seminarium. Już 15 marca 1941 roku bp Fulman pisał z Nowego Sącza do ks. Kruszyńskiego i dołączał zawiadomienie, jakie otrzymał z Krakowa, że Niemcy pozwolili na otwarcie seminariów w Generalnym Gubernatorstwie ${ }^{92}$. Wszelako warunkiem, jaki postawili, było przyjęcie tylko tych kandydatów, którzy rozpoczęli już formację seminaryjną przed wojną. W praktyce zatem, po odjęciu alumnów już wyświęconych w czasie okupacji, oznaczało to uruchomienie nauki jedynie dla roczników III-v. Dodatkowo, w odniesieniu do seminarium lubelskiego, władze okupacyjne zażądały urządzenia go poza Lublinem. Wybór padł na Krężnicę Jarą, gdzie postanowiono wykorzystać do tego celu dom będący własnością sióstr szarytek. Biskup był gotów odkupić go od zakonnic, o czym korespondował z ks. Kruszyńskim ${ }^{93}$. Martwił się jednak, o czym pisał z Nowego Sącza, że warunki materialne i brak funduszy na urządzenie seminarium, a zwłaszcza na opał w miesiącach zimowych, każą przesunąć uruchomienie seminarium do kwietnia ${ }^{94}$. Na początku grudnia sugerował jednak otworzenie zakładu w lutym, mając nadzieję na uzyskanie rekompensaty finansowej od władz okupacyjnych za używanie pomieszczeń kościelnych w Lublinie ${ }^{95}$. Idąc po linii oczekiwań wyrażanych przez biskupa wikariusz generalny w dniu 17 grudnia 1941 roku zawiadomił dziekanów, że seminarium zlokalizowane w Krężnicy ruszy w początkach nowego roku ${ }^{96}$. Rzeczywiście, wezwano alumnów, którzy zaczęli się zjeżdżać począwszy od 23 stycznia 1942 roku$^{97}$. W trudnych warunkach ruszyła praca formacyjna

\footnotetext{
${ }^{91}$ AAL, Rep 6o irb F16, k. 5or.

${ }^{92}$ Por. AAL, Dz IV 3, Korespondencja ze Stolicą Apostolską i pisma bp. M. L. Fulmana z lat 1939-1945, k. 4r-v.

${ }_{93}$ Por. AAL, Rep 6o irb F16, k. 58v.

${ }^{4}$ Por. tamże, k. 5or.

${ }^{95}$ Por. tamże, k. 51r.

${ }^{96}$ Por. AAL, Dz IV 3, k. 1or.

97 Por. Archiwum Metropolitalnego Seminarium Duchownego w Lublinie [dalej: AMSDL], XIII-H-1, Korespondencja seminarium duchownego 1871-1944, k. 22r; P. Stopniak, Diecezja $w$ latach 1939-1945. Sprawozdanie z losów i prac seminarium duchownego za lata 1939-1945, WDL 23 (1946) nr 7, s. 261.
} 
i wykłady. 6 lutego bp Fulman przesyłał z Nowego Sącza błogosławieństwo dla seminarium i wyrażał radość z faktu jego reaktywacji ${ }^{98}$. Nieco ponad miesiąc później dziękował za korespondencję otrzymaną od alumnów, którzy szczegółowo opisali porządek życia seminaryjnego ${ }^{99}$. Uruchomienie seminarium, nawet w skromnym kształcie, pozwalało liczyć na porządek i regularność w promowaniu kolejnych kandydatów do kapłaństwa, i to poczynając od biegnącego roku kalendarzowego. Działające seminarium legitymizowało też w jakimś sensie sprawowanie sakramentu święceń przez pasterza internowanego w Nowym Sączu.

Paradoksalnie, pomimo otwarcia tej instytucji, pierwszy z wyświęconych w 1942 roku przez bp. Fulmana kapłanów nie pochodził jednak z lubelskiego seminarium. Alumn Paweł Nieużyła był bowiem diakonem diecezji częstochowskiej. Zgłosił się on bezpośrednio do pasterza z prośbą o przyjęcie go w poczet duchowieństwa lubelskiego i wyświęcenie na prezbitera. W wyniku porozumienia z biskupem częstochowskim Teodorem Kubiną bp Fulman włączył kandydata 31 stycznia 1942 roku do lubelskiego prezbiterium, a nazajutrz udzielił mu święceń kapłańskich. O szczegółach swojej decyzji pasterz poinformował ks. Kruszyńskiego zawczasu, jeszcze 17 stycznia 1942 roku, obiecując odesłanie stosownych dokumentów do Lublina ${ }^{100}$. Tak też się stało i dokument sygnowany przez bp. Fulmana wkrótce po święceniach przeprowadzonych w Nowym Sączu, datowany 3 lutego, trafił do lubelskiej kurii ${ }^{101}$.

Odnośnie do święcenia najstarszych alumnów, pochodzących z przedwojennego III, a obecnie v rocznika, pasterz wyraził uwagę następującej treści: „Najbliższe święcenia mogą tylko być na wiosnę niewczesną, aby trochę pobyli w seminarium i duchowo, i naukowo przygotowali się do tego"102. Uczynił to tuż przed otwarciem seminarium w Krężnicy Jarej, w liście datowanym 3 grudnia 1941 roku. To, że seminarium zostało uruchomione dopiero nieco ponad miesiąc późnie,j zmodyfikowało zapewne opinię biskupa. 9 marca 1942 roku, pisząc do ks. Stopniaka i ks. Golińskiego proponował, aby nauka trwała dłużej, zasugerowana przez rektora połowa czerwca - jako

${ }^{98}$ Por. AAL, Rep 60 IIb F16, k. 56r.

99 Por. tamże, k. 57r.

${ }^{100}$ Por. tamże, k. 54V.

${ }^{101}$ Por. AAL, Rep 60 IIb N19, Akta osobowe ks. Pawła Nieużyły, bez paginacji, Zaświadczenie o udzieleniu święceń wystawione przez bp. M. L. Fulmana, 3 lutego 1942 r.

${ }^{102}$ AAL, Rep 60 irb F16, k. 51r. 
czas zakończenia roku akademickiego - wydała się biskupowi terminem zbyt wczesnym ${ }^{103}$. Ponowił zalecenie nieprzyspieszania nadmiernie końca roku, gdy 25 maja pisał, że wykłady zaczęły się dopiero od lutego ${ }^{104}$. W rzeczywistości nauka nie trwała jednak o wiele dłużej. Już bowiem 29 czerwca 1942 roku bp Fulman pisał do rektora seminarium o swojej gotowości na przyjęcie kandydatów do święceń. Rzecz była omówiona w czasie wizyty rektora u biskupa na początku miesiąca ${ }^{105}$. W liście biskup szczegółowo dodawał, że o ile pociąg nie przyjechałby na czas i alumni przybyliby do Nowego Sącza późnym wieczorem, to nie powinni już niepokoić pasterza nocną wizytą, ale zjawić się na plebanii następnego dnia, tj. w piątek, o godzinie 7.30. Święcenia miały bowiem zacząć się o godzinie 8 rano $^{106}$. Klerycy opuścili seminarium w środę 8 lipca, udając się przez Lublin do Nowego Sącza. $\mathrm{W}$ charakterze opiekuna grupy wystąpił wicerektor seminarium ks. Tomasz Wilczyński. Nazajutrz po przybyciu do celu podróży, tj. 10 lipca, bp Fulman udzielił święceń niższych Bolesławowi Szklarczykowi i Janowi Dudkowi jedynym spośród alumnów IV roku, którzy ich dotąd nie otrzymali. W tym samym dniu kandydaci do prezbiteratu z v roku - Józef Tatarczak, Edward Kowalski i Edmund Idziakowski - otrzymali święcenia subdiakonatu. Następnego dnia zostali wyświęceni na diakonów, zaś w niedzielę 12 lipca otrzymali święcenia kapłańskie ${ }^{107}$. Ostatni z tego rocznika studiów, Tadeusz Malec, z racji zdrowotnych nie mógł wziąć udziału w święceniach wraz ze swoimi kolegami. Do Nowego Sącza przybył zapewne dopiero 16 października 1942 roku, jako że 19 października otrzymał z rąk bp. Fulmana święcenia kapłańskie $^{108}$. Subdiakonat i diakonat przyjmował zapewne w dwóch kolejnych dniach, bezpośrednio poprzedzających tę datę.

W następnym roku akademickim 1942/1943 istniała już szansa na większy porządek w kwestii święceń, ponieważ nauka ruszyła normalnym trybem szkolnym. W rezultacie alumni Iv rocznika przybyli 6 maja 1943 roku do Nowego Sącza, gdzie nazajutrz z rąk pasterza otrzymali tonsurę i święcenia

\footnotetext{
${ }^{103}$ Por. AAL, Rep 6o irb F16, k. 57r.

${ }^{104}$ Por. tamże, k. 61r.

${ }^{105}$ Por. AAL, Dz IV 3670, Kronika Lubelskiego Seminarium Duchownego z siedzibą w Krężnicy Jarej, 23 stycznia 1942 - 21 grudnia 1943 r., k. 31v-32r.

${ }^{106}$ Por. AAL, Rep 60 irb F16, k. 62r.

${ }^{107}$ Por. AAL, Dz IV 3670, k. 42r.

${ }^{108}$ Por. AAL, Rep 60 irb M94, Akta osobowe ks. Tadeusza Malca, bez paginacji, Zaświadczenie o udzieleniu święceń wystawione przez bp. M. L. Fulmana, 19 października 1942 r.
} 
niższe ${ }^{109}$. Tydzień później bp Fulman pisał do rektora Stopniaka, że minorek udzielił zgodnie z programem i zachęcał do zaplanowania daty święceń wyższych dla v rocznika. Podpowiadał, zostawiając wszakże pole na dyskusję, że ze względu na niepewne losy wojny byłoby lepiej ustalić termin wcześniejszy. Proponował święcenia zaraz po zakończeniu wykładów, jeszcze przez rozpoczęciem sesji egzaminacyjnej ${ }^{110}$. Datę wskazaną przez rektora biskup zaakceptował listownie 21 maja 1943 roku. Dodał, że zgodnie z nabytym doświadczeniem alumnów należy przysłać w towarzystwie któregoś z seminaryjnych profesorów ${ }^{111}$. Skutkiem tego 25 czerwca ośmiu kleryków z roku v wraz z prokuratorem ks. Golińskim wyjechało do Nowego Sącza ${ }^{112}$. Byli to następujący alumni: Jan Dudek, Franciszek Gzik, Marian Nabielec, Jerzy Ochalski, Stanisław Witkowski, Stefan Sawecki, Franciszek Sysa i Bolesław Szklarczyk. W kolejnych dniach, od niedzieli do wtorku, tj. 27, 28 i 29 czerwca, biskup wyświęcał ich sukcesywnie na subdiakonów, diakonów i prezbiterów ${ }^{113}$.

Ostatnie święcenia, jakich udzielił bp Fulman w Nowym Sączu, odbyły się na początku 1944 roku. Zbliżający się front i trudne do przewidzenia wypadki wojenne dały impuls do przyspieszenia święceń ${ }^{114}$. Alumni ówczesnego v roku pod opieką ks. Golińskiego wyruszyli z Krężnicy 26 stycznia 1944 roku. Było ich jedenastu: Józef Bieńkowski, Jan Błaszczak, Bronisław

${ }^{109}$ Por. AAL, Dz IV 3670, k. 72r.

${ }^{110}$ Por. AAL, Rep 6o IIb F16, k. 69r.

${ }^{111}$ Por. tamże, k. 7or-v.

${ }^{112}$ Por. AAL, Dz IV 3670, k. 76 r.

${ }^{113}$ Por. AAL, Rep 6o IIb G63, Akta osobowe ks. Franciszka Gzika, bez paginacji, Prośba do bp. M. L. Fulmana o udzielenie święceń, 9 czerwca 1943 r. z adnotacją ks. P. Stopniaka; Rep 60 IIb N2O, Akta osobowe ks. Mariana Nabielca, bez paginacji, Prośba do bp. M. L. Fulmana o udzielenie święceń, 12 maja 1943 r. z adnotacją ks. P. Stopniaka; Rep 6o Irb O36, Akta osobowe ks. Jerzego Ochalskiego, bez paginacji, Prośba do bp. M. L. Fulmana o udzielenie święceń, 9 czerwca 1943 r. z adnotacją ks. P. Stopniaka; Rep 60 IIb S185, Akta osobowe ks. Franciszka Sysy, bez paginacji, Prośba do bp. M. L. Fulmana o udzielenie święceń, 10 czerwca 1943 r. z adnotacją ks. P. Stopniaka; Rep 60 Irb S193, Akta osobowe ks. Bolesława Szklarczyka, bez paginacji, Prośba do bp. M. L. Fulmana o udzielenie święceń, 10 czerwca 1943 r. z adnotacją ks. P. Stopniaka; Rep 6o IIb W63, Akta osobowe ks. Stanisława Witkowskiego, bez paginacji, Prośba do bp. M. L. Fulmana o udzielenie święceń, 12 maja 1943 r. z adnotacją ks. P. Stopniaka; Schematyzm diecezji zamojsko-lubaczowskiej, dz. cyt., s. 110.

${ }^{114}$ Por. J. Bieńkowski, Wspomnienie kapłana wyświęconego przez biskupa Fulmana w czasie wojny w Nowym Saczu, [w:] Biskup lubelski Marian Leon Fulman. Pedagog trudnych lat, dz. cyt., s. $233-234$. 
Falenta, Edward Kiełb, Michał Kot, Bolesław Kołtyś, Marian Niedziółka, Piotr Sadowski, Jan Skowronek, Zbigniew Starnawski oraz Stanisław Szubartowski. W piątek 28 stycznia o godzinie $8 \mathrm{w}$ prywatnej kaplicy biskupiej przyjęli oni święcenia subdiakonatu, a 29 stycznia święcenia diakonatu. Za każdym razem o godzinie 15 bp Fulman podejmował nowo wyświęconych alumnów herbatą na plebanii. Korzystając z okazji, wypytywał o warunki odbywania nauki w seminarium w Krężnicy. Po święceniach diakonatu zrobiono także okolicznościową fotografię z udziałem biskupa, miejscowego proboszcza i wyświęconych alumnów ${ }^{115}$. W niedzielę 30 stycznia miały miejsce święcenia prezbiteratu $\mathrm{z}$ udziałem kilkorga gości, którzy przybyli, aby uczestniczyć w podniosłej ceremonii liturgicznej. Bezpośrednio po liturgii bp Fulman przemówił do neoprezbiterów, podkreślając wagę posługi kapłańskiej. Słowa podziękowania wygłosił neoprezbiter pełniący zarazem funkcję dziekana seminaryjnego. Miejscowy proboszcz zaprosił zgromadzonych na wspólne śniadanie, po którym nowo wyświęceni udali się w drogę powrotną do seminarium, aby dokończyć studiów ${ }^{116}$.

Tak więc w ciągu swojego pobytu w Nowym Sączu bp Fulman wyświęcił na plebanii kolegiackiej łącznie 37 księży. Święceń prezbiteratu udzielał na przestrzeni dwóch i pół roku - od 15 czerwca 1941 do 30 stycznia 1944 roku.

\section{Obchody jubileuszu sakry biskupiej}

Szczególnym wydarzeniem w czasie internowania w Nowym Sączu była 25. rocznica święceń biskupich pasterza, przypadająca 17 listopada 1943 roku. Z tej okazji Pius xiI przesłał bp. Fulmanowi specjalny list gratulacyjny. Dokument, podpisany osobiście przez papieża, dotarł zapewne do adresata nie bez trudności. Datowany w Rzymie, u św. Piotra, 7 października 1943 roku, wart jest przytoczenia in extenso: „Venerabilis Frater, salutem et Apostolicam Benedictionem. Faustus quidem dies proxime illucescet, quo quintum ac vicesimum a suscepto episcopatu annum ipse implebis. Sed tamen, pro dolor, tibi facultas non datur una cum grege tuo eum celebrandi,

\footnotetext{
${ }^{115}$ Fotografia ta zachowała się w materiałach archiwalnych w parafii kolegiackiej w Nowym Sączu.

${ }^{116}$ Por. AMSDL, XIII-B-1, Kronika Lubelskiego Seminarium Duchownego od 10 stycznia 1944 , S. 4-5.
} 
quum a sede episcopali quattuor fere annos te abesse necesse fuerit, tanta cum animi moestitia, ut plane intelligitur. Dolores itaque tuos intime nos persentientes, nostra tibi verba communicare exoptamus, ut, proximo faustitatis tuae die, aliquid solatii adferamus. Omnium enim Ecclesiarum semper solliciti, peculiare studium in id sane contulimus, ut tua condicio allevaretur et bono tuae dioecesis fidelium convenienter consuleretur. Cuius profecto dioecesis nomen, tempore quidem pacis, praeclarum acceptumque in tota Polonia fuit propter Catholicam studiorum Universitatem, quae sapientiae exstat monumentum decessoris nostri venerabilis memoriae Pii XI, idemque insigne totius episcopatus Polonici et liberalitatis fidelium Poloniae catholicorum documentum. Huius autem Universitatis ipse, tamquam ordinarius dioecesanus, sollicitus custos, tot iuvenes Lublino discedere adspexisti, christiane fortiterque institutos, religiosis adfectos sensibus et desiderio flagrantes sese tradendi ad gentis Polonicae bonum spirituale, morale et sociale provehendum. Attamen florida pacis opera intermissa sunt atque immanis contentio cum ruinis cladibusque omnis generis infeliciter flagravit. Atque utinam tot innocentium animorum angores et supplicationes diem exoptatae tranquillitatis a Domino properent! Tibi itaque, Venerabilis Frater, ex corde ominamur, ut quam primum ad tuum gregem redire et pastorale opus redintegrare valeas. Divini interea praesidii in auspicium inque praecipuae nostrae dilectionis pignus Apostolicam Benedictionem tibi, Venerabilis Frater, cunctoque clero ac populo tuae curae demandato peramanter in Domino impertimus" ${ }^{\prime 17}$.

Dokument ten niewątpliwie bardzo ucieszył jubilata. Można się o tym przekonać $\mathrm{z}$ tonu odpowiedzi skierowanej przez bp. Fulmana do rektora seminarium lubelskiego ks. Piotra Stopniaka 6 grudnia 1943 roku. Pasterz przekonywał w nim, że adresat mylił się, co prawda, pragnąc w liście z życzeniami skierowanym do biskupa wyprowadzić z papieskiego tekstu jakiś dodatkowy tytuł, który jakoby nadawała lubelskiemu hierarsze Stolica Apostolska. Niemniej jednak podkreślał, że papież wyraził swoje uznanie dla wartości pracy biskupiej, a uczynił to w dokumencie tyleż zaszczytnym, co pięknym nawet pod względem estetyki jego wykonania ${ }^{118}$.

Sama uroczystość jubileuszowa przebiegała zgodnie z warunkami internowania, a więc na plebanii parafii kolegiackiej w Nowym Sączu. W pokoju

\footnotetext{
${ }^{117}$ AAL, Rep 6o IIb F16, k. 74r-v.

${ }^{118}$ Por. tamże, k. 92r.
} 
pełniącym na co dzień funkcję kaplicy biskupiej zgromadzili się przedstawiciele duchowieństwa lubelskiego. Pośród grona ośmiu kapłanów znajdował się wikariusz generalny ks. Kruszyński oraz świadczący biskupowi liczne usługi ks. Dziubiński. Ponadto zebrali się także miejscowi księża i siostry szarytki. Pokój wraz z ołtarzem udekorowany został białymi i jasnoczerwonymi chryzantemami, zapewne celowo nawiązującymi do symboliki polskich barw narodowych. Msza święta, $\mathrm{z}$ towarzyszeniem fisharmonii, rozpoczęła się od śpiewu sióstr zakonnych Ecce sacerdos magnus, a zakończyła hymnem Te Deum. Celebrował ją sam biskup-jubilat. Po liturgii przemówienie utrzymane w podniosłym i serdecznym tonie wygłosił ks. Kruszyński. Wzruszony pasterz odpowiedział słowami podziękowania. Wyrażając tęsknotę za diecezją, pokrzepił słuchaczy nadprzyrodzoną nadzieją, zapewnił o swojej modlitwie i poprosił w tym względzie o wzajemność. Następnie został odczytany i wręczony biskupowi, datowany 15 listopada w Tarnowie, dokument wystawiony z tej okazji przez tarnowską kapitułę katedralną. W jej imieniu podpisy złożyli ks. Stanisław Bulanda, ks. Jan Bochenek i ks. Julian Piskorz ${ }^{119}$. Uroczystość uwieńczył kantyk Magnificat ${ }^{120}$.

Warto zauważyć, że okrągła rocznica przyjęcia święceń biskupich stała się okazją do wyrażenia życzliwości pasterzowi także przez diecezjan, którzy z oczywistych powodów nie mogli złożyć hołdu, czci i wyrazów uszanowania osobiście. Zapewne z inicjatywy samych państwa Zamoyskich - ordynata Jana z żoną Różą - została przygotowana piękna laurka z inicjałami bp. Fulmana na pierwszej karcie oraz dołączonym zdjęciem kościoła w Zwierzyńcu.

${ }^{119}$ „Wasza Ekscelencjo, Najdostojniejszy Księże Biskupie! Z radością witamy dzień, w którym obchodzić będziesz uroczystość dwudziestopięciolecia święceń biskupich. Jeśli sam jubileusz kapłaństwa jest rzadkim i szczególnym darem Opatrzności Bożej, ileż bogatszym przed Bogiem i zasobniejszym w Jego łaski jest Twe sędziwe kapłaństwo, uwieńczone jubileuszem apostolskiego urzędu, wypełnionego żmudną, niestrudzoną pracą arcypasterską. Cieszymy się, Ekscelencjo, że zrządzeniem Opatrzności uroczysty ten dzień obchodzisz w diecezji tarnowskiej: całym sercem cieszymy się wraz z Tobą Ekscelencjo darem jubileuszu, jakim Cię dobroć Boża wyszczególnia i tak sami, jak i imieniem duchowieństwa i wiernych diecezji naszej składamy Ci najgorętsze życzenia: niech ten cenny dar Boży wypełni radością Twe serce, niech promieniuje otuchą i błogosławieństwem na serca Twoich bliskich, Twego kleru i ludu Twej pieczy poruczonego. Całujemy ze czcią dostojne Twe dłonie i prosimy dla nas wszystkich o Twe arcypasterskie błogosławieństwo" (AAL, Rep 6o IIb F16, k. 82r).

${ }^{120}$ Przebieg uroczystości dokładnie opisał ks. Roman Mazur, miejscowy proboszcz; AAL, Rep 60 IIb F16, k. 82r-83r. 
Środek wypełniały ogólne życzenia i wyrazy oddania oraz około 200 podpisów mieszkańców i pracowników stolicy ordynacji ${ }^{121}$.

Listów gratulacyjnych było zapewne bardzo dużo. Nie zachowały się jednak w źródłach. O intensywniejszej niż przeciętnie wymianie korespondencji w ostatnich tygodniach roku, a więc jubileuszowo-świąteczno-noworocznej, świadczyć mogą słowa bp. Fulmana zapisane 4 stycznia 1944 roku w liście do ks. Zdzisława Golińskiego. Pasterz przepraszał za opóźnienia w udzielaniu odpowiedzi na pisma adresata. Usprawiedliwiał się mnóstwem korespondencji, której w ostatnim czasie nie mógł podołać' ${ }^{122}$.

Trzeba pamiętać, że krótko po jubileuszu konsekracji biskup wspominał również rocznicę swojego ingresu do katedry lubelskiej. Stąd też wśród napływających życzeń znalazł się hołd wyrażony szczegółowymi wspomnieniami tamtego dnia, spisany 29 listopada 1943 roku przez ks. Stanisława Witkowskiego ${ }^{123}$.

\section{Samopoczucie i starania o zwolnienie}

Z wyją̧tkiem okazjonalnie przypadających miłych momentów i podniosłych chwil, do których należał przede wszystkim jubileusz przyjęcia sakry biskupiej, bp Fulman bardzo boleśnie przeżywał swoje internowanie z dala od diecezji. Wynikało to zapewne z dwóch przyczyn. Przede wszystkim doskwierało mu zawężenie pasterskiej aktywności, ograniczone formy kontaktu z duchowieństwem i diecezjanami, za których niezależnie od okoliczności czuł się odpowiedzialny. Już na początku pobytu w Nowym Sączu pisał do ks. Józefa Scipio del Campo, proboszcza w Kraśniku: „Tęskno mi za Lublinem - nie wiem, jak długo tu będę ${ }^{124}$. Ostatniego dnia tego samego roku do ks. Witolda Korsaka, proboszcza w Kiełczewicach, przesłał podobne słowa, podkreślając niezwykle mocno, że los diecezji bardzo go obchodzi1 ${ }^{125}$. Niespełna rok później do tego samego adresata skierował słowa: „Tęsknota za pracą pasterską wciąż mnie przygnębia"126 .5 maja 1941 roku pisał

\footnotetext{
${ }^{121}$ Por. AAL, Rep 6o irb F16, k. 86r-89r.

${ }^{122}$ Por. tamże, k. 96 r.

${ }^{123}$ Por. tamże, k. 9or-91v.

${ }^{124}$ A AL, Dz III 1, Biskup Marian Leon Fulman - posługa w diecezji w okresie 1944-1945, k. 2 r.

${ }^{125}$ Por. AAL, Rep 60 IIb F16, k. 42r.

${ }^{126}$ Tamże, k. 49r.
} 
do wikariusza generalnego ks. Józefa Kruszyńskiego: „U mnie nic nowego nie zaszło - ciężko na duszy, jak zwykle, i przyszłość najbliższa przeraża, bo wyobraźnia ją czarno zarysowuje. [...]. Dziękuję za informacje i proszę mi ich nadal nie skąpić, myślą bowiem i sercem jestem wśród was zawsze" ${ }^{127}$. Z kolei na Wielkanoc w 1942 roku żalił się w liście do ks. Kruszyńskiego: „Święta spędzam prawie samotnie, więc mi jest smutno i pomnaża to mój żałobny nastrój”"128.

Drugim powodem, dla którego biskup na ogół źle znosił pobyt w Nowym Sączu, był pogarszający się stan zdrowia, połączony z podeszłym wiekiem. 12 maja 1943 roku biskup pisał do ks. Zenona Kwieka: „Opóźniłem się z niniejszym pismem, aby podziękować mu za powinszowanie imieninowe, $\mathrm{z}$ powodu swych trudności osobistych, ale tym niemniej poczuwałem się do tego obowiązku. [...] tymczasem ręka chorobliwie działa i utrudniała pisanie. Od 1939 roku już tak coraz więcej drży. Wielka wada, ale nie z mojej winy" ${ }^{129}$. W liście z 21 maja 1943 roku do rektora seminarium ks. Piotra Stopniaka dodał w post scriptum gwoli usprawiedliwienia niewyraźnego charakteru pisma: „Mam nerwowe drżenie rąk przy pisaniu. Jest to nabytek niepożądany i przykry"130. W tych okolicznościach biskup postanowił sporządzić swój testament. Jego pierwsza wersja została spisana 24 stycznia 1942 roku, druga natomiast 15 czerwca 1943 roku. Treść obu była niezwykle prosta, zawierała kilka krótkich wskazań odnośnie do rozporządzenia ruchomym majątkiem biskupim, składającym się zasadniczo z rzeczy osobistych $^{131}$. Nie tyle więc sam tenor tych dokumentów, ile myśl o potrzebie ich przygotowania należy interpretować w kontekście własnej oceny zdrowia i utrzymującego się nastroju pasterza.

Zmartwienie biskupa potęgował brak środków materialnych. Pasterz nie miał stałych dochodów i pomimo - jak się można domyślać - życzliwej gościny na plebanii kolegiackiej musiał czuć się niezręcznie. Rozumiał, że długotrwały pobyt wymagał regulowania zaciągniętych w ten sposób zobowiązań. Można o tym wnioskować na podstawie korespondencji biskupiej $\mathrm{z}$ duchownymi decydentami w diecezji. Tak więc przykładowo 5 maja 1941

\footnotetext{
${ }^{127}$ AAL, Rep 60 IIb K111, k. 9v.

${ }^{128}$ AAL, Rep 60 IIb F16, k. 58v.

${ }^{129}$ Tamże, k. 68r.

${ }^{130}$ Tamże, k. 7ov.

${ }^{131}$ Por. tamże, k. 55r-v, 71r.
} 
roku biskup pisał do wikariusza generalnego, ks. Kruszyńskiego: „Na ks. Pawła [Dziubińskiego - J. M.] oczekuję, ale na próżno już od dwóch tygodni. Gdyby nie mógł przyjechać, to proszę o pieniądze drogą pocztową, o czym pisałem do ks. Pawła, bo obawiam się, żebym nie został bez pieniędzy. Jakieś trzy tysiące złotych trzeba by mieć na każdy wypadek do rozporządzenia na opłacenie utrzymania"132.

Złe znoszenie internowania przekładało się na intensywne poszukiwanie możliwości zwolnienia lub przeniesienia aresztu do diecezji. Już na wiosnę 1940 roku biskup wystosował w tej sprawie prośbę do władz niemieckich ${ }^{133}$. Następnie, przesławszy we wrześniu informację o miejscu swego pobytu nuncjuszowi w Berlinie, licząc zapewne po cichu na interwencję dyplomacji watykańskiej, bp Fulman ponowił w dniu 30 listopada prośbę do władz niemieckich o uwolnienie. Szef kancelarii Rzeszy odpowiedział wszakże pismem datowanym w Berlinie 10 grudnia, iż kwestię tę pozostawiono do rozstrzygnięcia generalnemu gubernatorowi Hansowi Frankowi ${ }^{134}$. W starania o uwolnienie biskupa zaangażowała się, co zrozumiałe, także lubelska kuria. 10 lutego 1941 roku nuncjusz apostolski w Niemczech bp Cesare Orsenigo pisał do ks. Kruszyńskiego, odpowiadając na list otrzymany z Lublina, że w sprawie bp. Fulmana nie zaniedbał żadnych możliwych do wykonania kroków ${ }^{135}$. Rezultat czynionych starań nie był jednak pomyślny. Szef dystryktu lubelskiego Generalnego Gubernatorstwa w liście z 6 marca 1941 roku skierowanym do bp. Fulmana odmówił mu prawa powrotu do diecezji ${ }^{136}$. Ze smutkiem napisał o tym bp Fulman do ks. Kruszyńskiego 10 marca, podkreślając swoje przygnębienie wywołane taką odpowiedzią ${ }^{137}$. Jakkolwiek ani pasterz, ani kuria nie zaniechali dalszych starań także w późniejszym czasie, to ich supliki były jednak stale załatwiane odmownie. Tak więc listem datowanym w Krakowie 12 grudnia 1941 roku władze Generalnego Gubernatorstwa odrzuciły kolejną prośbę biskupa o powrót do Lublina, wyrażoną przez niego nieco ponad tydzień wcześniej ${ }^{138}$. Natomiast 10 kwietnia 1942

\footnotetext{
${ }^{132}$ AAL, Rep 60 irb K111, k. 9r.

${ }^{133}$ Por. AAL, Rep 6o Irb F16, k. 47r.

${ }^{134}$ Por. tamże, k. 42r.

${ }^{135}$ Por. tamże, k. 44r.

${ }^{136}$ Por. tamże, k. 46r.

${ }^{137}$ Por. tamże, k. 47r.

${ }^{138}$ Por. tamże, k. 52 r.
} 
roku szef gubernialnej policji bezpieczeństwa i sD skierował pismo o takiej samej wymowie do kurii, odpowiadając na jej wniosek wystosowany jeszcze w poprzednim roku ${ }^{139}$.

Warto zauważyć, że Watykan, poruszony sytuacją i prośbami płynącymi od zainteresowanych, dokonywał prób intensywniejszego wpływania na władze niemieckie odnośnie do uwolnienia biskupa $\mathrm{z}$ więzienia. Co ciekawe, w marcu 1940 roku, w czasie wizyty Ribbentropa za Spiżową Bramą, kard. Luigi Maglione, sekretarz stanu Stolicy Apostolskiej, pośród wielu omawianych wówczas kwestii, nominatim wskazał los bp. Fulmana jako przykład niemieckich represji względem Kościoła na okupowanych polskich terytoriach ${ }^{140}$. Być może ten właśnie epizod miał na myśli wspomniany kard. Maglione, gdy 4 lutego 1943 roku pisał z Watykanu do bp. Fulmana o nieskuteczności starań o uwolnienie pasterza, udzielając mu nadzwyczajnych pełnomocnictw kościelnych ${ }^{141}$. Nie należy jednak wykluczać, że chodziło także o inne dodatkowe zabiegi w omawianej sprawie.

\section{Z powrotem w Lublinie}

Tak jak postanowienie z lutego 1940 roku o internowaniu bp. Fulmana w Nowym Sączu, tak również decyzja o jego zwolnieniu po z górą czterech latach zapadła nagle, bez formalnego uzasadnienia. Mianowicie 10 maja 1944 roku Heinrich Hamann, zatrudniony w tym czasie w dowództwie tajnej policji i SD, bez dodatkowych wyjaśnień poinformował biskupa o możliwości powrotu do Lublina, wręczając mu równocześnie stosowny dokument wydany przez Richarda Wendlera, gubernatora dystryktu lubelskiego Generalnego Gubernatorstwa ${ }^{142}$. Można się oczywiście domyślać, że gest ten, w perspektywie zbliżającego się frontu sowieckiego, był wyrazem zachęty skierowanej do duchowieństwa katolickiego i polskiego społeczeństwa, aby pobudzić je do stawienia oporu wobec komunistycznego niebezpieczeństwa. Sowieci byli już bowiem w Kołomyi, Tarnopolu i Łucku, oparli się także od południa na linii rzeki Prypeć.

\footnotetext{
${ }^{139}$ Por. tamże, k. 59r.

${ }^{140}$ Por. M. Wieliczko, Kontekst historyczny, art. cyt., s. 110-111.

${ }^{141}$ Por. AAL, Rep 60 IIb F16, k. 67r.

${ }^{142}$ Por. M. Wieliczko, Kontekst historyczny, art. cyt., s. 119.
} 
Pomimo uzyskania upragnionego zwolnienia $\mathrm{z}$ aresztu bp Fulman nie był w stanie natychmiast podjąć podróży do Lublina. Wynikało to przede wszystkim z niezadowalającego stanu zdrowia. Całodniowa, uciążliwa podróż zdawała się być zbyt dużym wyzwaniem. Jako że w następnych tygodniach działania wojenne przeniosły się na lewą stronę Bugu, a Lubelszczyznę zajęła Armia Czerwona, bp Fulman został na pół roku odcięty linią frontu od swojej diecezji. Dopiero oswobodzenie Nowego Sącza od Niemców 23 stycznia 1945 roku otworzyło na powrót możliwość przeniesienia się do Lublina. Gdy tylko pojawiły się sprzyjające warunki do odbycia bezpiecznej podróży, biskup wyruszył w drogę. W dniu 9 lutego 1945 roku opuścił Nowy Sącz i nazajutrz przybył do diecezji lubelskiej, zatrzymując się na plebanii w Niedrzwicy Kościelnej, gdzie był dłużej goszczony przez miejscowego proboszcza, ks. Stefana Galusińskiego. Wiązało się to z koniecznością przygotowania dla pasterza pokojów mieszkalnych w pałacu biskupim, choć miejscowa, lubelska prasa donosiła, że pasterz potrzebował także wypoczynku i czasu na regenerację zdrowia. W rezultacie biskup przybył do Lublina dopiero 24 lutego, a nazajutrz, w niedzielę 25 lutego 1945 roku odbył się jego ingres do katedry. Była to podniosła i wzruszająca uroczystość, w której uczestniczyły tłumy wiernych ${ }^{143}$.

W pierwszych miesiącach po powrocie do Lublina biskup starał się o odnowienie więzi z duchowieństwem i wiernymi diecezjanami. Stąd też dochodziło do licznych spotkań zarówno przy okazji zewnętrznych celebr, jak też i odwiedzin w pałacu biskupim ${ }^{144}$. Niemniej jednak czekały pasterza także bardzo poważne wyzwania, którym należało szybko stawić czoła.

Jednym z podstawowych zadań, którymi zajął się pasterz, było objęcie pomocą materialną skrajnie ubogich grup spośród duchowieństwa i wiernych świeckich. W tym celu biskup doprowadził do samoopodatkowania się kapłanów, aby wyjść naprzeciw m.in. księżom emerytom, pozbawionym źródeł utrzymania. Troska o świeckich wyrażała się natomiast w reaktywowaniu struktur Caritas, zarówno na poziomie ogólnodiecezjalnym, jak i parafialnym, oraz w ich skutecznym ukierunkowaniu na zaspokojenie konkretnych,

${ }^{143}$ Por. J. R. Marczewski, Powojenne losy biskupa Mariana Leona Fulmana, [w:] Pater Ecclesiae Lublinensis. Studia $w$ 65. rocznice śmierci biskupa Mariana Leona Fulmana (1866-1945), dz. cyt., s. 297-299.

${ }^{144}$ Por. tamże, s. 299-301. 
lokalnie rozpoznanych potrzeb ${ }^{145}$. Warto dodać, że biskup zatroszczył się również o zdobycie środków na Katolicki Uniwersytet Lubelski, który zresztą uczcił pasterza pierwszym po wojnie doktoratem honoris causa.

Poważnym zagadnieniem była sprawa odbudowy lubelskiej katedry. Biskup zdołał zjednoczyć wokół tej idei lokalne władze i miejscową społeczność. Doszło do powołania Komitetu Odbudowy Katedry. Pasterz stanął osobiście na czele jego prezydium. Wykonano prace eksperckie, zgromadzono materiał budowlany, w pomysłowy sposób apelowano o zbiorową ofiarność i zbierano niezbędne fundusze ${ }^{146}$.

W drugiej połowie 1945 roku jaśniejsze stawały się zasady, na których władza próbowała opierać byt społeczny. W zmieniających się okolicznościach nadzieje na odbudowę kraju w zgodzie $\mathrm{z}$ wartościami chrześcijańskimi i poszanowaniem tradycji narodowej ustępowały rozczarowaniu, któremu polscy biskupi dawali wyraz, zwłaszcza w kontekście zerwania przez rząd konkordatu ze Stolicą Apostolską. Co prawda bp Fulman, z uwagi na wiek i stan zdrowia, nie brał osobiście udziału w obradach episkopatu, ale w tym samym duchu przestrzegał diecezjan przed zakusami nowej władzy i niebezpieczeństwem porzucenia katolickiej etyki w życiu społecznym ${ }^{147}$.

Podjęte przez bp. Fulmana na przestrzeni roku 1945 działania tchnęły pierwotnym dynamizmem i charakteryzowały się leżącym u ich podstaw pogłębionym myśleniem koncepcyjnym. Niemniej jednak skala prac podjętych przez pasterza nie była duża. Wiązało się to $z$ jego kondycją fizyczną. Ubytek sił i zdrowia, jaki nastąpił w czasie wojennej tułaczki, był bardzo wyraźny. Ostatni raz publicznie pasterz pokazał się bodaj 18 listopada. Dokładnie miesiąc później funkcje życiowe wyczerpanego organizmu ustały. Śmierć bp. Fulmana nastąpiła w 8o. roku życia, nieco ponad dziesięć miesięcy po jego powrocie z Nowego Sącza.

\section{Epilog}

Internowanie bp. Fulmana w Nowym Sączu znalazło swój epilog po siedmiu dekadach od opuszczenia przez niego plebanii kolegiackiej. Otóż 9 lutego 2015 roku z inicjatywy metropolity lubelskiego abp. Stanisława Budzika,

\footnotetext{
${ }^{145}$ Por. tamże, s. 301-302.

${ }^{146}$ Por. tamże, s. 303-304.

${ }^{147}$ Por. tamże, s. 305-307.
} 
w porozumieniu z biskupem tarnowskim Andrzejem Jeżem, została zorganizowana w Nowym Sączu uroczystość poświęcona pamięci bp. Fulmana. Rozpoczęła ją Eucharystia sprawowana o godzinie 12 w kościele kolegiackim. Mszy św. przewodniczył i homilię wygłosił arcybiskup lubelski, koncelebrowali biskup tarnowski, lubelski biskup pomocniczy Mieczysław Cisło i licznie zgromadzeni kapłani. Obecni byli wśród nich członkowie nowosądeckiej kapituły kolegiackiej i miejscowego dekanatu Nowy Sącz-Centrum. Udział w koncelebrze wzięło kilkudziesięciu kapłanów z archidiecezji lubelskiej. Część z nich przybyła do Nowego Sącza w sposób zorganizowany, w charakterze reprezentantów duchowieństwa lubelskiego. Obecni byli przedstawiciele lubelskiej kurii, seminarium duchownego, Katolickiego Uniwersytetu Lubelskiego Jana Pawła II, osoby życia konsekrowanego, a także katecheci i młodzież z archidiecezji. Kulminacyjnym punktem obchodów było poświęcenie przez bp. Andrzeja Jeża i odsłonięcie przez abp. Stanisława Budzika tablicy upamiętniającej pobyt bp. Fulmana w Nowym Sączu. Została ona zamontowana wewnątrz budynku plebanii, na ścianie głównego korytarza wejściowego po lewej stronie. Tablica o wymiarach $60 \mathrm{~cm} \times 40 \mathrm{~cm}$ została wykonana ze szwedzkiego granitu Vanga i zaopatrzona w napis o następującej formie i treści:

W TYM KAPŁAŃSKIM DOMU MIESZKAE

OD 25 II 1940 DO 9 II 1945

BP MARIAN LEON FULMAN

PASTERZ DIECEZJI LUBELSKIEJ W LATACH 1918-1945

PIERWSZY WIELKI KANCLERZ KUL

ARESZTOWANY PRZEZ NIEMCÓW 17 XI 1939

OSADZONY NA ZAMKU LUBELSKIM

SKAZANY NA KARĘ ŚMIERCI

WIĘZIONY W ORANIENBURGU-SACHSENHAUSEN

PO ZAMIANIE WYROKU NA INTERNOWANIE

ZNALAZŁ GOŚCINNE PRZYJĘCIE, OPIEKĘ I SZACUNEK

NA TUTEJSZEJ PLEBANII

STĄD POTAJEMNIE KIEROWAE DIECEZJĄ LUBELSKĄ

TUTAJ SEKRETNIE UDZIELAŁ ŚWIĘCEŃ KAPŁAŃSKICH 


\author{
TABLICĘ TĘ KŁADĄ W 7O. ROCZNICĘ \\ UWOLNIENIA INTERNOWANEGO PASTERZA \\ METROPOLITA LUBELSKI STANISŁAW BUDZIK \\ I BISKUP TARNOWSKI ANDRZEJ JEŻ
}

\title{
Bibliografia
}

Atlas historyczny (archi)diecezji lubelskiej 1805-2010, red. H. Gapski, Lublin 2011. Encyklopedia katolicka, t. 5, red. L. Bieńkowski i in., Lublin 1989. Polski stownik biograficzny, t. 7, red. W. Konopczyński, Kraków 1948-1958. Polski słownik biograficzny, t. 45, red. A. Romanowski, Warszawa-Kraków 2008. Słownik biograficzny, s. 5-9 [mps w Archiwum Archidiecezjalnym Lubelskim]. Słownik polskich teologów katolickich, t. 5, red. L. Grzebień, Warszawa 1983. Goliński Z., Diecezja w latach 1939-1944. Lublin-Oranienburg-Nowy Sacz-Lublin. Lata 1939-1945 w życiu J.E. Ks. Bpa Fulmana, „Wiadomości Diecezjalne Lubelskie” 22 (1945) nr 3, s. 69-72; 22 (1945) nr 4, s. 102-109; 23 (1946) nr 1, s. 22-23. List pasterski bpa M. L. Fulmana z 1 grudnia 1918 r., „Wiadomości Diecezjalne Lubelskie" 1 (1918) nr 1, s. 1-19.

Pater Ecclesiae Lublinensis. Studia w 65. rocznicę śmierci biskupa Mariana Leona Fulmana (1866-1945), red. J. R. Marczewski, Lublin 2010.

Starnawski Z., Martyrologium duchowieństwa diecezji lubelskiej w latach 1939-1945. Walewander E., Biskup Marian Leon Fulman (1866-1945) - życie i dzieło, [w:] Biskup lubelski Marian Leon Fulman. Pedagog trudnych lat, red. E. Walewander, Lublin 2010, s. 123-130.

W Duchu i prawdzie. Wybrane sylwetki Kościoła lubelskiego (1805-2005), red. H. Misztal, Lublin 2005.

Ziółek J., Losy seminariów duchownych i wydziałów teologicznych w latach okupacji hitlerowskiej w Polsce, „Studia Płockie” 13 (1985), s. 72-90.

\section{Streszczenie}

Marian Leon Fulman był biskupem diecezji lubelskiej w latach 1918-1945. Gdy wybuchła druga wojna światowa został aresztowany przez Niemców pod fałszywym zarzutem posiadania broni. 27 listopada 1939 roku został skazany przez nazistowskie władze okupacyjne na karę śmierci. Karę tę zamieniono na ciężkie więzienie 
w Oranienburgu-Sachsenhausen. Biskup przebywał tam od 4 grudnia 1939 roku. Zapewne na skutek interwencji nuncjusza papieskiego w Berlinie bp Fulman został zwolniony z więzienia, ale nie pozwolono mu wrócić do Lublina. Został internowany w Nowym Sączu, gdzie od 25 lutego 1940 roku mieszkał na plebanii kościoła kolegiackiego pw. św. Małgorzaty. Miejscowy proboszcz ks. Roman Mazur przyjął go bardzo gościnnie. Biskup Fulman przez pięć lat kierował na odległość diecezją lubelską. Na plebanii miał do dyspozycji dwa pokoje. W jednym z nich została urządzona prywatna kaplica, gdzie biskup wyświęcił sekretnie 37 księży dla diecezji lubelskiej. W czasie internowania, 17 listopada 1943 roku, biskup obchodził jubileusz 25-lecia przyjęcia święceń biskupich. Z tej okazji otrzymał list gratulacyjny od papieża Piusa XII. W maju 1944 roku biskup uzyskał zgodę na powrót do swojej diecezji. Ze względu na podeszły wiek i zły stan zdrowia nie zdołał od razu rozpocząć powrotnej podróży. Wkrótce możliwość tę zablokowały działania na froncie wojennym. Opuścił Nowy Sącz dopiero 9 lutego 1945 roku. Umarł w Lublinie kilka miesięcy później. W 7o. rocznicę tego wydarzenia odbyły się w Nowym Sączu uroczystości z udziałem arcybiskupa lubelskiego Stanisława Budzika i biskupa tarnowskiego Andrzeja Jeża. Na świadectwo pobytu bp. Fulmana w Nowym Sączu 9 lutego 2015 roku umieszczono wewnątrz budynku plebanii kościoła pw. św. Małgorzaty specjalną pamiątkową tablicę.

\section{Słowa kluczowe}

biskup Marian Leon Fulman, diecezja lubelska, parafia pw. św. Małgorzaty w Nowym Sączu, druga wojna światowa, okupacja hitlerowska

\section{Summary}

Five years of internment. Marian Leon Fulman, Bishop of Lublin, in the presbytery of the collegiate church of Saint Margaret in Nowy Sącz

(1940-1945)

Marian Leon Fulman was the bishop of the Lublin diocese in the years 1918-1945. When the Second World War broke out, he was arrested by the Nazis under the false accusations of possession of arms. On $27^{\text {th }}$ November 1939 he was sentenced to death by the German authorities. The punishment was later changed into imprisonment in Oranienburg-Sachsenhausen. The Bishop remained there until $4^{\text {th }}$ December 1939. Apparently thanks to the intervention by the papal nuncio in Berlin, Fulman was released from prison, yet not allowed to come back to Lublin. 
He was interned in Nowy Sącz, where he lived in the presbytery of the collegiate church of Saint Margaret until $25^{\text {th }}$ February 1940. The local parish priest, Roman Mazur, welcomed him warmly. Bishop Fulman was the head of the Lublin diocese from a distance. He had two rooms at his disposal. In one of them he organized a private chapel, where he secretly ordained 37 priests for the Lublin diocese. During the period of his internment, on $17^{\text {th }}$ November 1943, Fulman celebrated the $25^{\text {th }}$ anniversary of his ordination as a bishop. On this occasion he received a letter of congratulation from the Pope Pius XII. In May 1944 the Bishop was granted permission to return to his diocese. Due to his old age and bad health he did not start the journey. Soon such a possibility was out of the question due to war activity on the front. It was not until $9^{\text {th }}$ February 1945 that the Bishop left Nowy Sacz. He died in Lublin a few months later. The Archbishop of Lublin Stanisław Budzik and the Bishop of Tarnów Andrzej Jeż participated in the ceremony commemorating the $70^{\text {th }}$ anniversary of the Fulman's termination of the internment. On $9^{\text {th }}$ February 2015 a special commemorative plaque was placed inside the presbytery of the collegiate church of Saint Margaret to commemorate Bishop Fulman's stay in Nowy Sącz.

\section{Keywords}

Bishop Marian Leon Fulman, Diocese of Lublin, Church of Saint Margaret in Nowy Sącz, Second World War, Nazi occupation 